\title{
Dynamic investment, debt structure and debt overhang
}

\author{
Liu Gan ${ }^{a}$ Xin Xia ${ }^{b, *}$ Hai Zhang ${ }^{c,}$ \\ ${ }^{a}$ School of Finance, Jiangxi University of Finance and Economics, Nanchang, China \\ ${ }^{b}$ School of Finance, Zhongnan University of Economics and Law, Wuhan, China \\ ${ }^{c}$ Department of Accounting and Finance, Strathclyde Business School, UK
}

\begin{abstract}
We study the impact of the optimal debt and priority structure on the intertwined corporate financing and investment decisions in a dynamic trade-off model, where the firm simultaneously uses bank and market debt for project financing. Private bank debt is renegotiable during financial distress, thus it avoids inefficient and costly bankruptcy losses should the renegotiation be successful. Our model shows: (i) Shareholders' bargaining power, renegotiation friction, growth potential, and bankruptcy costs limits bank debt capacity; (ii) The substitution effect between bank and market debt dominates in most cases; (iii) Bank debt issuance reduces the bankruptcy risk and speeds firm investment, which mitigates the debt overhand effect; (iv) Debt priority structure has a monotonic positive effect on firms' optimal capital structure, the net benefit of mixed debt financing, and firm valuation, the effect of which is much stronger for weaker shareholders, therefore, it would be optimal to place bank debt as senior for firm value maximization; (v) The benefit of mixed debt financing is significant (a firm valuation boost between 5\%-10\%) compared to either the bank debt exclusive or market debt exclusive debt structure.
\end{abstract}

JEL Classification: G13; G32; G33

Keywords: Debt Structure, Debt Overhang, Dynamic investment, Renegotiation friction, Shareholders' bargaining power

\footnotetext{
${ }^{*}$ Corresponding author.

E-mail addresses: ganliu@jxufe.edu.en (Liu Gan), doublexinxiao@yeah.net (Xin Xia), hai.zhang@strath.ac.uk.
} 


\section{Introduction}

Most existing trade-off capital structure models assume: (i) a firm is optimally financed by a single type of debt that cannot be renegotiated due to the dispersion of its creditors, providing no insights on heterogeneous debt and priority structures (Leland 1994, 1998, Hackbarth and Mauer 2012, Diamond and He 2014, Sundaresan, Wang and Yang 2015); (ii) a firm's financing decision is dependent of its real investment decision (Fan and Sundaresan 2000, Hackbarth, Hennessy and Leland 2007), ignoring the most important intertwined debt overhang effect which is first analyzed by Myers (1977). However, extensive empirical studies indeed recognize heterogeneity in the sources of debt financing (Rauh and Sufi 2010, Colla, Ippolito and Li 2013, Becker and Ivashina 2014, Chen, Maslar and Serfling 2020) and the negative impact of debt in place on firm investment (Hennessy 2004, Alanis, Chava and Kumar 2018).

A large body of recent research has already begun the task of incorporating either the dynamic investment or various debt structures separately into trade-off capital structure models. Hackbarth, Hennessy and Leland (2007) assume debt is issued at the same exogenous investment timing under different debt structures. However, Hackbarth, Hennessy and Leland ignore the fact that the debt structure and investment decisions interact with each other, thus the optimal timing of investment varies under different debt structures and so do the timing of debt issuance. Hackbarth and Mauer (2012), Diamond and He (2014), Sundaresan et al. (2015) indeed investigate the interaction between financing and investment decisions in a dynamic trade-off model, none of them considers the renegotiable bank debt in their framework. Morellec, Valta and Zhdanov (2015), Shibata and Nishihara (2015b) incorporate both the dynamic investment and debt structures into their model to investigate the intertwined effect between a firm's marginal financing decision (market debt verse bank debt) and its investment decision. Nevertheless, neither do they consider a mixture of market and bank debt financing.

Therefore, we adopt a setting that resembles Hackbarth, Hennessy and Leland (2007) and extend their model by incorporating both dynamic investment (Sundaresan and Wang 2007) and various debt structures. In our model, a firm's optimal capital structure are driven by renegotiation cost, bankruptcy cost, tax shield benefit and investment benefits. Private bank debt is renegotiable during financial distress, thus it avoids inefficient and costly bankruptcy losses should the renegotiation be successful. However, bank debt does not always dominate market debt as there exists renegotiation friction specifying a probability of renegotiation failure (Davydenko and Strebulaev 2007, Favara, Schroth and Valta 2012, Morellec, Valta and Zhdanov 2015), which justifies borrowers demand for market debt. Compared with firms issuing only bank debt or market debt, our model predicts a firm has the highest market leverage (debt capacity) when issuing a mixture of bank and market debt. Our model also shows bank debt dominates market debt in most cases because of its ability of avoiding inefficient bankruptcy via renegotiation. The result turns around as bank debt loses its edge when the renegotiation friction is higher (either a higher shareholders' bargaining power or a higher probability of renegotiation failure) or the tax shield benefit is larger for market debt.

We also incorporate in our analysis several realistic factors that drive the firm's mix of debt financing and investment decisions. First, following Fan and Sundaresan (2000), Sundaresan and Wang (2007), Davydenko and Strebulaev (2007) among others, we incorporate varying shareholders' bargaining power and renegotiation friction in debt renegotiation. Our model shows that bank debt, on average, dominates market debt in most cases except when the renegotiation friction is higher (either a higher shareholders' bargaining power 
or a higher probability of renegotiation failure) or the tax shield benefit is larger for market debt. In such cases, market debt substitutes more bank debt as the latter loses its edge to market debt.

Second, unlike the dynamic investment models developed in Morellec, Valta and Zhdanov, Shibata and Nishihara assuming firms choose only either bank or market debt financing, our parsimonious model is able to investigate the interactions between mixed debt financing and firm investment decisions. We find the benefit of mixed debt financing is significantly large (a firm valuation boosts between 5\%-10\%) compared to either bank debt exclusive or market debt exclusive debt structures.

Third, we consider a general debt priority structure in our model including three prevalent used debt structures, namely senior bank debt, junior bank debt, and pari passu, in practice. Our model predicts that priority structure has a monotonic positive effect on firms' optimal capital structure, the net benefit of mixed debt financing, and firm valuation, the effect of which is much stronger for weaker shareholders (with lower bargaining power).

We also explore with our model the negative effect of debt overhang on corporate expansion investment decisions. Our model predicts that, in general, the higher level of existing debt, particular market debt, in place deters firm investment, which is consistent with (Myers 1977, Hackbarth and Mauer 2012, Diamond and He 2014). Interestingly, given a constant high level of market debt in place, issuing more bank debt actually accelerates firm investment when bank debt is granted senior. This is because the renegotiation feature of bank debt allows shareholders to extract part of renegotiation surplus from bank debt creditors, which, to some extent, mitigates the debt overhang effect.

Related literature. In order to highlight the contributions of our article, following Hackbarth, Hennessy and Leland (2007), we summarize the features of related structural trade-off models in Table 1. To be more specific, this table collects two main strands of recent literature on strategic debt service (columns (1-2))and dynamic trade-off models with endogenous investment (column (6)).

Fan and Sundaresan (2000) adopt a Nash bargaining game in debt renegotiation to investigate the impact of varying bargaining power on renegotiation and payout policies. Similarly, Sundaresan and Wang (2007) provide a parsimonious framework to model strategic interactions between equity holders and debt holders stronger equity and its impact on ex-ante growth option exercising decisions and firm value. Sundaresan and Wang find that equity holders bargaining power lowers private debt capacity, reduces firm value, and delays corporate investment.

Our paper contributes to a growing literature that examines the interaction between corporate financing and investment decisions in dynamic trade-off models. Hackbarth and Mauer (2012) develop a dynamic mode to study debt structure and its impact on corporate investment. They find jointly optimal capital and priority structures can virtually eliminate debt overhang resulting from agency conflicts. Diamond and He (2014) provide a thorough analysis of the negative effects of debt maturity on firms' current and future investments decisions, which is often referred as to debt overhang. Diamond and He show that Myers suggestion, that short-term debt could possibly mitigate debt overhang problem, can be reversed under different settings even that short-term debt depends less on firm value. Our study complements Hackbarth and Mauer, Diamond and $\mathrm{He}$ by incorporating strategic debt renegotiation in the analysis of corporate financing and investment decisions.

Following Hackbarth, Hennessy and Leland (2007), Diamond and He (2014), Wong and Yu (2020), we 
extend the classical Leland-type capital structure framework to a dynamic structural model that simultaneously incorporates both flexible investment opportunities and heterogeneous (mixed) debt financing. Our article is mostly related to that by Hackbarth, Hennessy and Leland (2007). First, inspired by Diamond and He (2014), Wong and Yu (2020), we incorporate investment decision into Hackbarth, Hennessy and Leland model. Since the debt structure and investment decisions interact with each other, the optimal timing of investment varies under different debt structures and so do the timing of debt issuance. Thus, it is necessary to incorporate the investment decision into a dynamic trade-off model. Second, following Fan and Sundaresan (2000), Sundaresan and Wang (2007), we accommodate varying shareholders' bargaining powers in debt renegotiation when a firm is under financial distress. Third, we consider a reasonable restoration of contractual debt payment and associated tax benefits should EBIT improve. In Hackbarth, Hennessy and Leland's model, once the debt renegotiation begins, the debt payment concessions continue forever, regardless of whether the EBIT has recovered or not. Fourth, we consider that both the bank debt holders and market debt holders receive a part of the remaining firm value upon bankruptcy. Thus, we are able to obtain an interior solution of the mixed debt structure, which means that the optimal bank debt and market debt interact with each other. Our result is more realistic than that in Hackbarth, Hennessy and Leland, who substantially assume that the market debt holders receive nothing upon bankruptcy in the main part of their model. In such an extreme case, they can only obtain a corner solution of the mixed debt structure, which means that the optimal bank debt and market debt are determined separately and the optimal financing strategy is to issue the bank debt until its full capacity first, and then issue a positive amount of market debt afterward.

Table 1: Related structural trade-off models

\begin{tabular}{lcccccc}
\hline & $\begin{array}{c}\text { Negotiable } \\
\text { debt }\end{array}$ & $\begin{array}{c}\text { Market } \\
\text { debt }\end{array}$ & $\begin{array}{c}\text { Optimal } \\
\text { priority }\end{array}$ & $\begin{array}{c}\text { Bargaining } \\
\text { power }\end{array}$ & $\begin{array}{c}\text { Closed-form } \\
\text { solution }\end{array}$ & $\begin{array}{c}\text { Investment } \\
\text { endogenous }\end{array}$ \\
& $(1)$ & $(2)$ & $(3)$ & $(4)$ & $(5)$ & $(6)$ \\
\hline Leland (1994) & $\mathrm{N}$ & $\mathrm{Y}$ & $\mathrm{N}$ & $\mathrm{N}$ & $\mathrm{Y}$ & $\mathrm{N}$ \\
Fan and Sundaresan (2000) & $\mathrm{Y}$ & $\mathrm{N}$ & $\mathrm{N}$ & $\mathrm{Y}$ & $\mathrm{Y}$ & $\mathrm{N}$ \\
Hackbarth et al. (2007) & $\mathrm{Y}$ & $\mathrm{Y}$ & $\mathrm{Y}$ & $\mathrm{Y}$ & $\mathrm{Y}$ & $\mathrm{N}$ \\
Sundaresan and Wang (2007) & $\mathrm{Y}$ & $\mathrm{N}$ & $\mathrm{N}$ & $\mathrm{Y}$ & $\mathrm{Y}$ & $\mathrm{Y}$ \\
Hackbarth and Mauer (2012) & $\mathrm{N}$ & $\mathrm{Y}$ & $\mathrm{Y}$ & $\mathrm{N}$ & $\mathrm{Y}$ & $\mathrm{Y}$ \\
Diamond and He (2014) & $\mathrm{N}$ & $\mathrm{Y}$ & $\mathrm{N}$ & $\mathrm{N}$ & $\mathrm{Y}$ & $\mathrm{Y}$ \\
Morellec et al. (2015) & $\mathrm{Y}$ & $\mathrm{Y}$ & $\mathrm{N}$ & $\mathrm{Y}$ & $\mathrm{Y}$ & $\mathrm{Y}$ \\
Shibata and Nishihara (2015b) & $\mathrm{Y}$ & $\mathrm{Y}$ & $\mathrm{N}$ & $\mathrm{Y}$ & $\mathrm{Y}$ & $\mathrm{Y}$ \\
Sundaresan et al. (2015) & $\mathrm{N}$ & $\mathrm{Y}$ & $\mathrm{Y}$ & $\mathrm{N}$ & $\mathrm{Y}$ & $\mathrm{Y}$ \\
Wong and Yu (2020) & $\mathrm{Y}$ & $\mathrm{N}$ & $\mathrm{N}$ & $\mathrm{Y}$ & $\mathrm{Y}$ & $\mathrm{Y}$ \\
Gan-Xia-Zhang (2020) & $\mathrm{Y}$ & $\mathrm{Y}$ & $\mathrm{Y}$ & $\mathrm{Y}$ & $\mathrm{Y}$ & $\mathrm{Y}$ \\
\hline
\end{tabular}

The present paper is also related to a set of papers that studies the effects of mixed debt structure and priority structure (see Morellec, Valta and Zhdanov (2015), Shibata and Nishihara (2015b)) on corporate 
financing and investment decisions. Morellec, Valta and Zhdanov (2015) investigate the choice between bank and market debt in a firms marginal financing decision and its effects on investment. Shibata and Nishihara (2015b) develop a model to study the impact of various debt structures under issuance limit constraints on corporate investment, financing, and debt choice decisions. However, neither Morellec, Valta and Zhdanov nor Shibata and Nishihara considers the mixed debt financing as the debt choice in their models is assumed to be mutually exclusive. To the best of the authors' knowledge, this paper is the first attempt to investigate the impact of debt heterogeneity and its priority structure on corporate investment in a dynamic trade-off model where firms simultaneously use bank and market debt. By doing so, we can jointly determine the optimal bank and market debt mix in our model and shed light on how optimal mixed debt financing affects firm investment and valuation.

The reminder of this article is organized as follows. Section 2 extends the classical Leland-type capital structure framework by developing a dynamic trade-off model that simultaneously incorporates both flexible investment opportunities and heterogeneous (mixed) debt financing. Section 3 solves the model and derives closed-form solutions for corporate securities, optimal ex-post investment, renegotiation, and default polices, and optimal capital structure, followed by an examination of two alternative debt structures (market debt only and bank debt only) in Section 4. Section 5 discusses key model implications as well as some novel empirical implications generated from our model. Finally, Section 6 concludes. Technical stuff is gathered in Appendix A.

\section{Model setup}

Following Hackbarth, Hennessy and Leland (2007) and Diamond and He (2014), we extend the classical Leland-type capital structure framework to a dynamic structural model which simultaneously incorporates both flexible investment opportunities and heterogeneous (mixed) debt financing. Throughout the paper, we assume assets can be continuously traded in a complete and arbitrage-free market.

\subsection{Firm cash flows and investment opportunity}

Consider a firm with assets-in-place that generates an operating cash flow $X_{t}$, which evolves according to

$$
d X_{t}=\left(\mu+\bar{i}\left(X_{t}\right)\right) X_{t} d t+\sigma X_{t} d Z_{t}
$$

where the constants $\mu$ and $\sigma$ are the baseline growth rate and volatility of the cash flow, respectively; $\left\{Z_{t}: t \geq 0\right\}$ is a standard Brownian motion defined on the risk-neutral probability space, $(\Omega, \mathcal{F}, \mathbb{P})$. At any time $t$, the firm's cash flow growth rate is subject to the investment rate $\bar{i}(X)$, which is dependent on the current cash flow level $X$. Following Diamond and He (2014) and Wong and Yu (2020), we assume that the investment policy is controlled by equity holders and takes a binary value, in that

$$
\bar{i}(X)=\left\{\begin{array}{lll}
i, & \text { if } \quad X \geq X_{i} \\
0, & \text { if } \quad X<X_{i} .
\end{array}\right.
$$

Here, $X_{i}$ denotes the investment threshold, indicating a firm invests when its cash flow level exceeds $X_{i}$. The random first passage time, $T^{i}$, that the firm's cash flow level reaches the threshold, $X_{i}$, from below satisfies 
$T^{i}=\inf \left\{t \geq 0, X_{t}=X_{i}\right\}$. In addition, investment incurs a cost, which is given by $\phi \bar{i}(X) X$ (Diamond and He 2014).

Let the constant $r>0$ denote the risk-free interest rate. The after-tax present value of an all-equity financed firm that always invests is given by

$$
\mathbb{E}_{t}\left[\int_{t}^{\infty} e^{-r(u-t)}\left((1-\tau) X_{u}-\phi i X_{u}\right) d u\right]=\frac{(1-\tau)(1-\tilde{\phi} i)}{r-(\mu+i)} X_{t},
$$

where $\tilde{\phi} \equiv \frac{\phi}{(1-\tau)}$ and $\tau \in(0,1)$ denotes the corporate tax rate. We denote by $U_{i} \equiv \frac{(1-\tau)(1-\tilde{\phi} i)}{r-(\mu+i)}$ to facilitate exposition. For convergence, we assume that the interest rate is higher than the maximal (risk-neutral) cash flow growth rate, in that $r>\mu+i$. Conversely, when the firm never invests, its present value of asset is given by $U_{0} X_{t}$, where $U_{0} \equiv \frac{1-\tau}{r-\mu}$. As in Wong and Yu (2020), we assume $\Pi \equiv U_{i}-U_{0}>0$ and define $\Pi / U_{0}$ to measure the profitability of the firm's future investment opportunities.

\subsection{Debt structure and bankruptcy}

Featuring the debt heterogeneity, our model assumes that the firm issues two classes of perpetual debt, namely bank debt and market debt. The bank debt has a promised coupon payment $b$, and $c$ for the market debt. In our benchmark case, bank debt is senior to market debt upon bankruptcy, consistent with the theoretical prediction in Hackbarth et al. (2007) and the empirical evidence reported by Rauh and Sufi (2010). That is, the junior market debt lenders will not receive payoff until the senior bank lenders are fully paid off at bankruptcy. We will investigate alternative debt priority structure later in the model analysis. Moreover, the coupon payment to the market lenders cannot be modified (write down) outside the formal bankruptcy process, a feature which is presented by Leland (1994) and supported by the empirical evidence in Gilson et al. (1990), Asquith et al. (1994). Following Hackbarth, Hennessy and Leland (2007), Shibata and Nishihara (2015b), Morellec, Valta and Zhdanov (2015), the bank debt coupon payment in our model can be reduced in the course of private workouts. ${ }^{1}$

When the firm falls into financial distress (i.e., a credit event occurs) at any future time $t$, shareholders initiate a private workout to renegotiate the coupon payment of bank debt. Let $T^{n}=\inf \left\{t \geq 0, X_{t}=X_{n}\right\}$ be the first passage time of the firm's cash flow, $X_{t}$, to reach the renegotiation (coupon reduction) threshold, $X_{n}$, from above. Thus, the renegotiation threshold splits the firm's cash flow into two regions: the normal region and the renegotiation region. Following Fan and Sundaresan (2000), Sundaresan and Wang (2007), the reduced coupon, denoted by $s(X)$, is a function of the firm's current cash flow level in the renegotiation region. Moreover, the tax shield of the bank debt is temporarily suspended in the renegotiation region. When the firm's cash flow level recovers to the normal region, the tax shield is restored. In addition, we assume that the debt renegotiation process is formalized as Nash bargaining, which is consistent with Fan and Sundaresan (2000), Hackbarth et al. (2007), Sundaresan and Wang (2007). As a result of bargaining, both shareholders and bank lenders obtain a fraction of the total surplus according to their bargaining powers $\eta$ and $1-\eta$ respectively.

Debt renegotiation might fail, as discussed in Davydenko and Strebulaev (2007), Favara, Schroth and Valta (2012), Morellec, Valta and Zhdanov (2015), our model captures such friction by defining a failure

\footnotetext{
${ }^{1}$ Since the dispersion of debt holders, the market debt cannot be renegotiated when the firm falls into financial distress.
} 
probability, $q$, of the debt renegotiation. Once the renegotiation fails, shareholders declare bankruptcy and the firm is liquidated. In such a scenario, the absolute priority rule (APR) is enforced and the outside option value for the shareholder is zero. Furthermore, the new owner will not relever the restructured firm and lose any future investment opportunities. Let $\alpha \in[0,1]$ denote the bankruptcy loss rate. Thus, at bankruptcy, both market debt holders and bank debt holders jointly share the liquidation value $L\left(X_{t}\right)$, which is equal to

$$
L\left(X_{t}\right)=(1-\alpha) U_{0} X_{t}
$$

Specifically, senior bank debt holders receive the reservation value $R_{b}\left(X_{t}\right)$ which is given by

$$
R_{b}\left(X_{t}\right)=\min \left\{\frac{b}{r}, L\left(X_{t}\right)\right\}
$$

while junior market debt holders collect the remaining value $R_{m}\left(X_{t}\right)$ that satisfies

$$
R_{m}\left(X_{t}\right)=\max \left\{L\left(X_{t}\right)-\frac{b}{r}, 0\right\} .
$$

In the benchmark model, we follow Hackbarth, Hennessy and Leland (2007) to consider a general priority structure. Let the constant $\zeta \in(0,1]$ denote the fraction of the liquidation value $L(X)$ that the bank lenders receive (i.e., $\left.R_{b}(X)=\zeta L(X)\right)$ when the bankruptcy occurs. Then, the market debt holders obtain the remaining value which is given by $R_{m}=(1-\zeta) L(X)$. In the extreme case of $\zeta=1$, it captures the senior bank debt case defined in Equations (3)-(4). Because the bank lender would reject any debt coupon payment less than $b$ once $L(X)<b / r$ were not hold (Hackbarth, Hennessy and Leland 2007). Thus, the model with $\zeta=1$ provides the claim valuations for the senior bank debt case. Conversely, in the extreme case of $\zeta=0$, it provides the claim valuations for the senior market debt case.

By contrast, provided that the debt renegotiation is successful, subsequently to the coupon reduction of bank debt, the firm might still default on the coupon payment if its fundamental condition continues to deteriorate. The first passage time of the firm's cash flow, $X_{t}$, to hit the bankruptcy threshold, $X_{d}$, from above is defined as $T^{d}=\inf \left\{t \geq 0, X_{t}=X_{d}\right\}$. At that time, the firm is finally liquidated and outside debt holders receive the corresponding liquidation value.

\section{Investment, financing and valuation of corporate securities}

We first derive the solutions of corporate securities and the shareholder's endogenous decisions given the firm's debt structure. Subsequently, we analyze the firm's optimal debt structure.

Although the ordering of decisions for renegotiation, investment and bankruptcy is endogenous, we follow Wong and $\mathrm{Yu}$ (2020) to assume the sequence of decisions timings for a firm financed with equity, bank debt and market debt are described as follows:

$$
X_{d}<X_{i}<X_{n}
$$

This ordering simplifies the presentation of our model solutions, and it always holds with the realistic model parameter constellations. Let $E_{n}(X), B_{n}(X)$ and $D_{n}(X)$ denote the values of equity, bank debt and market debt in the renegotiation region $\left(X_{d}<X<X_{n}\right)$, respectively. Then, let us denoted by $V(X), E(X), B(X)$ 
and $D(X)$ the values of equity, bank debt and market debt in the normal region $\left(X>X_{n}\right)$, respectively. The total firm value, denoted by $V(X)$ for $X>X_{n}$ and $V_{n}(X)$ for $X_{d}<X<X_{n}$, is therefore defined by the sum of the values of equity, bank debt and market debt.

\subsection{Total firm value}

As in Sundaresan and Wang (2007), to obtain the market values of equity and debt, we should provide the total firm value in advance. In the normal region $\left(X>X_{n}\right)$, the operating cash flows of the total firm at each time $t$ is given by $(1-\tau) X_{t}+\tau(b+c)-\phi i X_{t}$, because the shareholder has realized the investment policy defined in Equation (1). By contrast, in the renegotiation region $\left(X_{d}<X<X_{n}\right)$, the operating cash flows of the total firm at each time $t$ is given by $(1-\tau) X_{t}+\tau(b)-\phi \bar{i}\left(X_{t}\right) X_{t}$. Moreover, the capital gains over each time interval $[t, t+d t]$ is given by $\mathbb{E}[d V]$ for $X>X_{n}$ and $\mathbb{E}\left[d V_{n}\right]$ for $X_{d}<X<X_{n}$, where $\mathbb{E}$ is an expectation operator. Applying the dynamic programming method and Itô's lemma, we have that market value of total firm satisfies the following ordinary differential equations (ODEs):

$$
\left\{\begin{array}{llc}
r V(X)=(1-\tau) X+\tau(b+c)-\phi i X+(\mu+i) X V^{\prime}(X)+\frac{1}{2} \sigma^{2} X^{2} V^{\prime \prime}(X), & \text { if } \quad X \geq X_{n} \\
r V_{n}(X)=(1-\tau) X+\tau c-\phi \bar{i}(X) X+(\mu+\bar{i}(X)) X V^{\prime}(X)+\frac{1}{2} \sigma^{2} X^{2} V^{\prime \prime}(X), & \text { if } \quad X_{d} \leq X<X_{n}
\end{array}\right.
$$

given the shareholder's optimal investment threshold $X_{i}$, optimal renegotiation threshold $X_{n}$ and optimal default threshold $X_{d}$. Noticing that the investment threshold $X_{i}$ divides the firm's cash flow into two intervals: investment regions for $X>X_{i}$ with $\bar{i}(X)=i$ and no-investment regions for $X_{d}<X<X_{i}$ with $\bar{i}(X)=0$.

Equation (5)is simultaneously solved by using the following six boundary conditions:

$$
\left\{\begin{array}{lll}
\lim _{X \rightarrow \infty} V(X) / X<+\infty, & \text { the standard no-bubble condition; } & \\
V\left(X_{n}\right)=(1-q) V_{n}\left(X_{n}\right)+q L\left(X_{n}\right), & \text { the value-matching condition at } & X_{n} ; \\
V^{\prime}\left(X_{n}\right)=(1-q) V_{n}^{\prime}\left(X_{n}\right)+q(1-\alpha) U_{0}, & \text { the smooth-pasting condition at } & X_{n} ; \\
\lim _{X \downarrow X_{i}} V_{n}(X)=\lim _{X \uparrow X_{i}} V_{n}(X), & \text { the value-matching condition at } & X_{i} ; \\
\lim _{X \downarrow X_{i}} V_{n}^{\prime}(X)=\lim _{X \uparrow X_{i}} V_{n}^{\prime}(X), & \text { the smooth-pasting condition at } & X_{i} ; \\
V_{n}\left(X_{d}\right)=L\left(X_{d}\right), & \text { the value-matching condition at } & X_{d}
\end{array}\right.
$$

In Equation (6), because the possibility of bankruptcy is negligible when $\delta$ is sufficiently large, we impose the no-bubble condition for the firm to rule out speculative bubbles. The value-matching and smooth-pasting conditions at the renegotiation threshold $X_{n}$ demonstrate that the value function of the total firm should be continuous and smooth at $X_{n}$. At that instant, since the firm's liquidation probability is reduced by a factor $q$, the total firm value is increased. Similarly, the value function of the total firm are continuity and smoothness conditions at the investment threshold $X_{i}$. The value-matching condition at the default threshold $X_{d}$ demonstrates an equality between the total firm value and the liquidation value at final bankruptcy. Then, the total firm value is summarized as follows. 
Proposition 1 Given the shareholder's optimal investment threshold $X_{i}$, optimal renegotiation threshold $X_{n}$ and optimal default threshold $X_{d}$, in the normal region $\left(X>X_{n}\right)$, the total firm value $V(X)$ satisfies

$$
V(X)=U_{i} X+\frac{\tau(b+c)}{r}+G_{1} X^{\gamma_{1}}
$$

and in the renegotiation region $\left(X_{d}<X<X_{n}\right)$, the total firm value $V_{n}(X)$ is given by

$$
V_{n}(X)=\left\{\begin{array}{lll}
U_{i} X+\frac{\tau c}{r}+G_{2} X^{\gamma_{1}}+G_{3} X^{\gamma_{2}}, & \text { if } \quad X_{i} \leq X<X_{n}, \\
U_{0} X+\frac{\tau c}{r}+G_{4} X^{\beta_{1}}+G_{5} X^{\beta_{2}}, & \text { if } \quad X_{d}<X<X_{i} .
\end{array}\right.
$$

Here, the constants $\gamma_{1}, \gamma_{2}, \beta_{1}, \beta_{2}, G_{1}, G_{2}, G_{3}, G_{4}$ and $G_{5}$ are defined in Appendix A.

The expression for the total firm value is intuitive. When the firm in the normal region $\left(X>X_{n}\right)$, the total firm value includes three components. The first two terms are the sum of the expected presented value of the unlevered firm who always invests and the expected presented value of the tax shield benefit when there is no default risk. The last term captures the changes in value for possible future financial distress and temporarily stopping investment. In the renegotiation region $\left(X_{d}<X<X_{n}\right)$, the firm faces two different regions depending on whether shareholders stop investment. First, on interval $\left[X_{i}, X_{n}\right)$, the total firm value consists of three components. The first two terms are the sum of the expected presented value of the unlevered firm who always invests and the expected presented value of the tax shield benefit when there is no default risk. The last two terms capture the value adjustments when the firm enters into the normal region again or enters into the no-investment region in the future. Second, on the interval $\left[X_{d}, X_{i}\right)$, the firm is in the no-investment region, the value of market debt also consists of three components. The first two terms are the sum of the expected presented value of the unlevered firm who never invests and the expected presented value of the tax shield benefit when there is no default risk. The last two terms capture the changes in value by considering both possible future defaults and entering the investment region again.

\subsection{Debt value and strategic debt service}

To obtain the values of bank debt and market debt, we first solve the Nash bargaining game between shareholders and bank lenders. With a successful renegotiation, shareholders and bank lenders bargain to determine the allocation of the total surplus $V_{n}(X)-D_{n}(X)-\zeta L(X)$. The surplus amount that bank lenders can extract (i.e., the value of bank debt) satisfies

$$
B_{n}\left(X ; \bar{i}(X), X_{i}\right)=\underset{\hat{B}_{n}}{\arg \max }\left[V_{n}\left(X ; \bar{i}(X), X_{i}\right)-D_{n}\left(X ; \bar{i}(X), X_{i}\right)-\hat{B}_{n}\right]^{\eta}\left[\hat{B}_{n}-\zeta L(X)\right]^{1-\eta},
$$

anticipating the shareholder's optimal investment policy $\bar{i}(X)$. Solving the above model yields the market value of bank debt in the renegotiation region $\left(X_{d}<X<X_{n}\right)$

$$
B_{n}\left(X ; \bar{i}(X), X_{i}\right)=R_{b}(X)+(1-\eta)\left(V_{n}\left(X ; \bar{i}(X), X_{i}\right)-D_{n}\left(X ; \bar{i}(X), X_{i}\right)-\zeta L(X)\right) .
$$

The market value of bank debt in Equation (7) is given by bank lenders' reservation value plus a fraction $1-\eta$ of the renegotiation surplus from avoiding costly bankruptcy. Similarly, the market value of equity $E_{n}(X)$ in the renegotiation region is given by

$$
E_{n}\left(X ; \bar{i}(X), X_{i}\right)=\eta\left(V_{n}\left(X ; \bar{i}(X), X_{i}\right)-D_{n}\left(X ; \bar{i}(X), X_{i}\right)-\zeta L(X)\right) .
$$


Equation (8) shows that shareholders obtain a fraction $\eta$ of the renegotiation surplus from avoiding costly bankruptcy.

In the normal region $\left(X>X_{n}\right)$, bank lenders receive the coupon payment $b$ at each time. Moreover, they also receive capital gains $\mathbb{E}[d B]$ over each time interval $[t, t+d t]$. By the standard variation principle, the market value of bank debt $B(X)$ for $X>X_{n}$ is solved by the following ODE:

$$
r B(X)=b+(\mu+i) X B^{\prime}(X)+\frac{\sigma^{2}}{2} X^{2} B^{\prime \prime}(X),
$$

given the bank lender's rational expectation of the shareholder's realized investment policy $\bar{i}(X)=i$. In Equation (9), the no arbitrage rule implies that the required return for the bank debt (the left-hand side) should equal to the sum of the debt service (the first term on the right-hand side) and the expected change in the market value of bank debt on any time interval (the last two terms).

The market value of bank debt is solved subject to the following value-matching and no-bubble conditions:

$$
\begin{cases}B\left(X_{n}\right)=(1-q) B_{n}\left(X_{n}\right)+q \zeta L\left(X_{n}\right), & \text { the value-matching condition at } X_{n} \\ \lim _{X \rightarrow \infty} B(X)=\frac{b}{r}, & \text { the standard no-bubble condition. }\end{cases}
$$

The value-matching condition shows that at the renegotiation, bank lenders receive the expected value, which is equal to the weighted average of the bank debt value after restructuring and the reservation value. The standard no-bubble condition shows that bank debt becomes risk-free when the firm's cash flow level becomes sufficiently large, and thus, its value equals the expected present value of the perpetual debt service b. Using standard calculations as in Leland (1994), we can derive the value function $B(X)$ for $X>X_{n}$. Then, we can summarize the market debt value as the following proposition.

Proposition 2 Given the shareholder's optimal investment threshold $X_{i}$, optimal renegotiation threshold $X_{n}$ and optimal default threshold $X_{d}$, in the normal region $\left(X>X_{n}\right)$, bank lenders bearing a coupon flow of $b$ is worth:

$$
B(X)=\frac{b}{r}+\left[(1-q) B_{n}\left(X_{n}\right)+q \zeta L\left(X_{n}\right)-\frac{b}{r}\right]\left(\frac{X}{X_{n}}\right)^{\gamma_{1}}
$$

and in the renegotiation region $\left(X_{d}<X<X_{n}\right)$, the value function $B_{n}(X)$ for bank lenders bearing a reduced coupon flow of $s(X)$ is given in Equation (7).

We derive the market debt values as follows. Anticipating the shareholder's realized investment policy $i(X)=i$ in the normal region $\left(X>X_{n}\right)$, the value of market debt $D(X)$ satisfies

$$
r D(X)=c+(\mu+i) X D^{\prime}(X)+\frac{\sigma^{2}}{2} X^{2} D^{\prime \prime}(X)
$$

In the renegotiation region $\left(X_{d}<X<X_{n}\right)$, the market debt value $D_{n}(X)$ satisfies

$$
r D_{n}(X)=c+(\mu+\bar{i}(X)) X D_{n}^{\prime}(X)+\frac{\sigma^{2}}{2} X^{2} D_{n}^{\prime \prime}(X)
$$

which is dependent on the shareholder's optimal investment policy $\bar{i}(X)$ and the corresponding investment threshold $X_{i}$. In Equations (10) and (11), the left-hand sides represent the return required by market debt 
holders. The right-hand sides are the sum of debt service (the first term) and the expected change in the value of market debt on any time interval (the last two terms).

Equations (10) and (11) are jointly solved subject to the following six boundary conditions:

$$
\left\{\begin{array}{lll}
\lim _{X \rightarrow \infty} D(X)=\frac{c}{r}, & \text { the standard no-bubble condition; } & \\
D\left(X_{n}\right)=(1-q) D_{n}\left(X_{n}\right)+q(1-\zeta) L\left(X_{n}\right), & \text { the value-matching condition at } & X_{n} ; \\
D^{\prime}\left(X_{n}\right)=(1-q) D_{n}^{\prime}\left(X_{n}\right)+q(1-\alpha)(1-\zeta) U_{0}, & \text { the smooth-pasting condition at } & X_{n} ; \\
\lim _{X \downarrow X_{i}} D_{n}(X)=\lim _{X \uparrow X_{i}} D_{n}(X), & \text { the value-matching condition at } & X_{i} ; \\
\lim _{X \downarrow X_{i}} D_{n}^{\prime}(X)=\lim _{X \uparrow X_{i}} D_{n}^{\prime}(X) ; & \text { the smooth-pasting condition at } & X_{i} ; \\
D_{n}\left(X_{d}\right)=(1-\zeta) L\left(X_{d}\right), & \text { the value-matching condition at } & X_{d}
\end{array}\right.
$$

Then, using Equations (10)-(12), we can summarize the solutions for the value of market debt as the following proposition.

Proposition 3 Given the shareholder's optimal investment threshold $X_{i}$, optimal renegotiation threshold $X_{n}$ and optimal default threshold $X_{d}$, in the normal region $\left(X>X_{n}\right)$, the value of market debt $D(X)$ satisfies

$$
D(X)=\frac{c}{r}+A_{1} X^{\gamma_{1}}, \quad \text { if } \quad X \geq X_{n},
$$

and in the renegotiation region $\left(X_{d}<X<X_{n}\right)$, the value of market debt $D_{n}(X)$ is given by

$$
D_{n}(X)=\left\{\begin{array}{lll}
\frac{c}{r}+A_{2} X^{\gamma_{1}}+A_{3} X^{\gamma_{2}}, & \text { if } & X_{i} \leq X<X_{n}, \\
\frac{c}{r}+A_{4} X^{\beta_{1}}+A_{5} X^{\beta_{2}}, & \text { if } & X_{d}<X<X_{i} .
\end{array}\right.
$$

Here, the constants $A_{1}, A_{2}, A_{3}, A_{4}$ and $A_{5}$ are defined in Appendix $A$.

Proposition 3 shows that in the normal region $\left(X>X_{n}\right)$, the value of market debt is given by the sum of the expected value of the perpetual coupon flow absent default risk $(c / r)$ and the changes in value for possible future financial distress and temporarily stopping investment. In the renegotiation region $\left(X_{d}<X<X_{n}\right)$, the firm faces two different regions depending on whether shareholders stop investment. First, on the interval $\left[X_{i}, X_{n}\right)$, the value of market debt consists of three components. The first term is the default-free debt value $c / r$. The last two terms capture the value adjustments when the firm enters into the normal region again or enters into the no-investment region in the future. Second, on the interval $\left[X_{d}, X_{i}\right)$, the firm is in the no-investment region, the value of market debt also consists of three components. The default-free debt value $c / r$ is given in the first term. The last two terms capture the changes in value by considering both possible future default and entering the investment region again.

\subsection{Equity value and endogenous decisions}

In the normal region $\left(X>X_{n}\right)$, the after-tax cash flow net of the investment cost (i.e., dividend) to shareholders is $(1-\tau)\left(X_{t}-b-c\right)-\phi i X_{t}$ at each time $t$. Then, the equity value function $E(X)$ for $X>X_{n}$ must satisfy the following ODE:

$$
r E(X)=(1-\tau)(X-b-c)-\phi i X+(\mu+i) X E^{\prime}(X)+\frac{\sigma^{2}}{2} X^{2} E^{\prime \prime}(X) .
$$


Equation (15) represents that the required return for holding the firm's equity (the left-hand side) equals the after-tax cash flow net of the investment cost plus the expected change in equity value. Solving the value function $E(X)$ is subject to the following value-matching and no-bubble conditions:

$$
\begin{cases}E\left(X_{n}\right)=(1-q) E_{n}\left(X_{n}\right), & \text { the value-matching condition at } \\ \lim _{X \rightarrow \infty} \frac{E(X)}{X}<+\infty, & \text { the standard no-bubble condition. }\end{cases}
$$

Then, we can led to the following proposition.

Proposition 4 Given the shareholder's optimal investment threshold $X_{i}$, optimal renegotiation threshold $X_{n}$ and optimal default threshold $X_{d}$, in the normal region $\left(X>X_{n}\right)$, the market value of equity $E(X)$ satisfies

$$
E(X)=\left(U_{i} X-(1-\tau) \frac{b+c}{r}\right)+\left[(1-q) E_{n}\left(X_{n}\right)-U_{i} X_{n}+(1-\tau) \frac{b+c}{r}\right]\left(\frac{X}{X_{n}}\right)^{\gamma_{1}}
$$

and in the renegotiation region $\left(X_{d}<X<X_{n}\right)$, the market value of equity $E_{n}(X)$ is given in Equation (8)

Equation (16) represents that the equity value function in the normal region is given by the sum of the expected present value of a perpetual flow of dividend and the adjustment in equity value caused by potential future debt renegotiation, stopping investment and going bankrupt. Shareholders select the renegotiation threshold $X_{n}$ to maximize equity value. Thus, the following smooth-pasting condition at the threshold level $X_{n}$ should be hold:

$$
E^{\prime}\left(X_{n}\right)=(1-q) E_{n}^{\prime}\left(X_{n}\right)
$$

The above condition translates into nonlinear equations which can be solved numerically due to no closedform solutions.

In the renegotiation region $\left(X_{d}<X<X_{n}\right)$, the equity value function $E_{n}(X)$ captures the ex post optimal investment and bankruptcy decisions selected by shareholders, and the equity value function $E(X)$ for $X>X_{n}$ satisfies the following ODE:

$$
r E_{n}(X)=\max _{\bar{i}(X) \in\{0, i\}}(1-\tau)(X-c)-s(X)-\phi \bar{i}(X) X+(\mu+\bar{i}(X)) X E_{n}^{\prime}(X)+\frac{\sigma^{2}}{2} X^{2} E_{n}^{\prime \prime}(X),
$$

subject to the value-matching boundary conditions at $X_{n}, X_{i}$, and $X_{d}$, and the smooth-pasting condition at $X_{n}$ and $X_{i}$. The first order condition (FOC) for investment $i(X)$ generates the optimal investment threshold which satisfies

$$
E_{n}^{\prime}\left(X_{i}\right)=\phi
$$

The equity value $E_{n}(X)$ for $X_{d}<X<X_{n}$ is given in Equation (8). For the bankruptcy threshold, the smooth-pasting of $E_{n}(X)$ at $X_{d}$ delivers the endogenous bankruptcy threshold:

$$
E_{n}^{\prime}\left(X_{d}\right)=0
$$

Again, the endogenous default threshold $X_{d}$ is determined uniquely by a nonlinear equation which will be solved numerically. 


\subsection{Optimal debt structure}

We now turn to the discussion of the firm's optimal debt structure. At the initial financing time, shareholders select the optimal mixture of bank debt and market debt to maximize the ex-ante equity value, which is equal to the initial firm value. That is, the firm's optimal debt structure is solved by the following optimization problem:

$$
\left\{b^{*}\left(X_{0}\right), c^{*}\left(X_{0}\right)\right\}=\arg \max _{b, c}\left\{E\left(X_{0} ; b, c\right)+B\left(X_{0} ; b, c\right)+D\left(X_{0} ; b, c\right)\right\},
$$

given the shareholder's ex-post optimal investment, debt renegotiation and default policies. The optimal coupon payment on bank and market debt cannot be obtained analytically. The optimal leverage ratio of the firm, $L R$, is measured by the ratio of the market value of the total debt to the market value of the firm, which is given by

$$
L R\left(X_{0} ; b^{*}\left(X_{0}\right), c^{*}\left(X_{0}\right)\right)=\frac{B\left(X_{0} ; b^{*}\left(X_{0}\right), c^{*}\left(X_{0}\right)+D\left(X_{0} ; b^{*}\left(X_{0}\right), c^{*}\left(X_{0}\right)\right.\right.}{V\left(X_{0} ; b^{*}\left(X_{0}\right), c^{*}\left(X_{0}\right)\right)} .
$$

\subsection{Equal priority structure}

In this subsection, we turn to consider another priority structure that the bank debt and market debt have equal priority (pari passu) upon bankruptcy. The total liquidation value of the firm is given in Equation (2), the reservation value for the bank debt and market debt at bankruptcy are given by

$$
\begin{aligned}
& R_{b}(X)=\frac{b}{b+c} L(X), \\
& R_{m}\left(X_{t}\right)=\frac{c}{b+c} L(X),
\end{aligned}
$$

respectively. Under the new priority structure, the valuation for total firm, equity, bank debt and market debt are similar to those of the baseline model, given the parameter $\zeta=\frac{b}{b+c}$.

\section{Alternative debt structures}

In the previous literature, the firm is either absent for bank debt financing or for future flexible investment opportunities. The main contribution of this paper is that we develop a dynamic trade-off model of capital structure by incorporating both the debt financing heterogeneity and future dynamic investment opportunities, which generates additional important implications in firms' financing and investment decisions. Before demonstrating our main results, we here provide two extreme benchmark models with each considers only one homogeneous debt issuance.

\subsection{Exclusive market debt structure}

First, we consider the model with firms financed with equity and market debt exclusively. Let $V_{c}(X)$, $E_{c}(X)$, and $D_{c}(X)$ denote the values of total firm, equity and market debt, respectively. The corresponding default and investment thresholds, which are denoted by $X_{d}^{c}$ and $X_{i}^{c}$, respectively. 
At each time $t$, the firm deliver a cash flow $(1-\tau)\left(X_{t}-b\right)-\phi \bar{i}\left(X_{t}\right) X_{t}$ to shareholders, and the market value of equity satisfies

$$
r E_{c}(X)=\max _{\bar{i}(X) \in\{0, i\}}(1-\tau)(X-c)-\phi \bar{i}(X) X+(\mu+\bar{i}(X)) X E_{c}^{\prime}(X)+\frac{\sigma^{2}}{2} X^{2} E_{c}^{\prime \prime}(X),
$$

subject to the following four boundary conditions:

$$
\left\{\begin{array}{lll}
\lim _{X \rightarrow \infty} E_{c}(X) / X<+\infty, & \text { the standard no-bubble condition; } & \\
\lim _{X \downarrow X_{i}^{c}} E_{c}(X)=\lim _{X \uparrow X_{i}^{c}} E_{c}(X), & \text { the value-matching condition at } & X_{i}^{c} ; \\
\lim _{X \downarrow X_{i}^{c}} E_{c}^{\prime}(X)=\lim _{X \uparrow X_{i}^{c}} E_{c}^{\prime}(X), & \text { the smooth-pasting condition at } & X_{i}^{c} \\
E_{c}\left(X_{d}^{c}\right)=0, & \text { the value-matching condition at } & X_{d}^{c}
\end{array}\right.
$$

In addition, in Equation (17), the FOC for $i(X)$ yields an optimal investment threshold $X_{i}^{c}$ with $E_{c}^{\prime}\left(X_{i}^{c}\right)=\phi$ so that the investment policy satisfies Equation (1). The solution for (17) can be summarized as follows.

Proposition 5 For firms financed with equity and market debt exclusively, in the normal operating region $\left(X>X_{d}^{c}\right)$, given the shareholder's investment policy and bankruptcy threshold, the market value of equity $E_{c}(X)$ satisfies

$$
E_{c}(X)= \begin{cases}\left(U_{i} X-(1-\tau) \frac{c}{r}\right)+C_{1} X^{\gamma_{1}}, & \text { if } \quad X_{i}^{c} \leq X, \\ \left(U_{0} X-(1-\tau) \frac{c}{r}\right)+C_{2} X^{\beta_{1}}+C_{3} X^{\beta_{2}}, & \text { if } \quad X_{d}^{c}<X<X_{i}^{c} .\end{cases}
$$

where the coefficients $C_{1}, C_{2}$ and $C_{3}$ are defined in Appendix A.

The interpretation for Equation (18) is given as follows. In the investment region $\left(X>X_{i}^{c}\right)$, the righthand side of equity value demonstrates the expected present value of a perpetual flow of dividend plus the change in equity value caused by potential future stopping investment and going bankrupt. In the no-investment region $X_{d}^{c}<X<X_{i}^{c}$, the first term on the right-hand side of equity value represents the expected present value of dividend when shareholders do not have flexibility to invest and default on the debt. The last two terms captures the adjustment in equity value caused by potential future entering into the investment region again and going bankrupt. The optimal bankruptcy threshold, selected by shareholders, is determined by the following smooth-pasting condition

$$
\lim _{X \downarrow X_{d}^{c}} E_{c}^{\prime}(X)=0
$$

which translates into a nonlinear equation.

Anticipating the shareholder's investment and default policies, the value of market debt $D_{c}(X)$ satisfies

$$
r D_{c}(X)=c+(\mu+\bar{i}(X)) X D_{c}^{\prime}(X)+\frac{\sigma^{2}}{2} X^{2} D_{c}^{\prime \prime}(X),
$$

subject to the following four boundaries conditions:

$$
\left\{\begin{array}{lll}
\lim _{X \rightarrow \infty} D_{c}(X)=\frac{c}{r}, & \text { the standard no-bubble condition; } & \\
\lim _{X \downarrow X_{i}^{c}} D_{c}(X)=\lim _{X \uparrow X_{i}^{c}} D_{c}(X), & \text { the value-matching condition at } & X_{i}^{c} ; \\
\lim _{X \downarrow X_{i}^{c}} D_{c}^{\prime}(X)=\lim _{X \uparrow X_{i}^{c}} D_{c}^{\prime}(X), & \text { the smooth-pasting condition at } & X_{i}^{c} \\
D_{c}\left(X_{d}^{c}\right)=L\left(X_{d}^{c}\right), & \text { the value-matching condition at } & X_{d}^{c}
\end{array}\right.
$$


Proposition 6 For firms financed with equity and market debt exclusively, in the normal operating region $\left(X>X_{d}^{c}\right)$, given the shareholder's optimal investment threshold $X_{i}^{c}$ and bankruptcy threshold $X_{d}^{c}$, the value of market debt $D_{c}(X)$ satisfies

$$
D_{c}(X)=\left\{\begin{array}{ll}
\frac{c}{r}+F_{1} X^{\gamma_{1}}, & \text { if } \quad X_{i}^{c} \leq X, \\
\frac{c}{r}+F_{2} X^{\beta_{1}}+F_{3} X^{\beta_{2}}, & \text { if } \quad X_{d}^{c}<X<X_{i}^{c}
\end{array} .\right.
$$

where the coefficients $F_{1}, F_{2}$ and $F_{3}$ are defined in Appendix A.

The expressions given in Equation (19) for the value of market debt are similar to those provided for the value of market debt in Equations (13) and (14). We thus obtain a similar interpretation. Finally, the optimal capital structure decisions, chosen to maximize the ex-ante equity value (initial firm value), is determined by $c_{c}^{*}\left(X_{0}\right)=\arg \max _{c} V_{c}\left(X_{0} ; c\right)$.

\subsection{Exclusive bank debt structure}

We now consider firms financed with equity and bank debt exclusively, which is similar to Wong and Yu (2020). To facilitate exposition, let us denote by $E_{b}(X), B_{b}(X)$ and $V_{b}(X)$ the equity value and the debt value, and the firm value, respectively, in the normal region. Moreover, let $E_{n b}(X), B_{n b}(X)$ and $V_{n b}(X)$ denote the equity value and the debt value, and the firm value, respectively, in the renegotiation region. The corresponding investment, bankruptcy, and renegotiation thresholds are denoted by $X_{i}^{b}, X_{d}^{b}$ and $X_{n}^{b}$, respectively.

Under the exclusive bank debt structure (i.e., $c=0$ in the baseline model), as shown in Fan and Sundaresan (2000), Sundaresan and Wang (2007), Wong and Yu (2020), the presence of renegotiation with strategic debt service ensures that shareholders will never go bankrupt in equilibrium, i.e., the bankruptcy threshold $X_{d}^{b}=0$. Moreover, the ODEs for the total firm value are similar to those of the baseline model (i.e., Equations. (8) and (9)), given the specified coupon levels for bank debt. Solving the total firm value subjects to the standard no bubble condition, the value-matching boundary conditions at $X_{n}^{b}, X_{i}^{b}$, and $X_{d}^{b}$, and the smooth-pasting condition at $X_{n}^{b}$ and $X_{i}^{b}$.

Then, we can provide the following proposition.

Proposition 7 For firms financed with equity and bank debt exclusively, given the shareholder's optimal investment threshold $X_{i}^{b}$, optimal renegotiation threshold $X_{n}^{b}$ and optimal default threshold $X_{d}^{b}$, in the normal region $\left(X>X_{n}\right)$, the total firm value $V_{b}(X)$ satisfies

$$
V_{b}(X)=U_{i} X+\frac{\tau b}{r}+H_{1} X^{\gamma_{1}}, \quad \text { if } \quad X \geq X_{n}^{b}
$$

and for $X_{d}<X<X_{n}$, the total firm value $V_{b n}(X)$ is given by

$$
V_{n b}(X)= \begin{cases}U_{i} X+H_{2} X^{\gamma_{1}}+H_{3} X^{\gamma_{2}}, & \text { if } \quad X_{i}^{b} \leq X<X_{n}^{b}, \\ U_{0} X+H_{4} X^{\beta_{2}}, & \text { if } \quad X<X_{i}^{b} .\end{cases}
$$

where the constants $H_{1}, H_{2}, H_{3}$, and $H_{4}$ are given in Appendix $A$. 
In the absence of market debt financing (i.e., $c=0$ ), the Nash bargaining result between shareholders and bank lenders implies that the equity value $E_{n b}(X)$ and the bank debt value $B_{n b}(X)$ in the renegotiation region $\left(X_{i}^{b}<X<X_{n}^{b}\right)$ are simply given by

$$
\begin{aligned}
& \left.B_{n b}\left(X ; \bar{i}(X), X_{i}\right)=(1-\alpha) L(X)+(1-\eta)\left(V_{n b}\left(X ; \bar{i}(X), X_{i}^{b}\right)-(1-\alpha) L(X)\right)\right), \\
& E_{n b}\left(X ; \bar{i}(X), X_{i}\right)=\eta\left(V_{n b}\left(X ; \bar{i}(X), X_{i}^{b}\right)-(1-\alpha) L(X)\right) .
\end{aligned}
$$

Under such a situation, the optimal investment policy is also given by the condition $E_{n}^{b^{\prime}}\left(X_{i}^{b}\right)=\phi$, which derives the following proposition (see the Appendix A.3 of Wong and Yu (2020) for the proof).

Proposition 8 When the marginal benefit of investment is sufficiently large relative to the marginal cost of investment $\phi$, shareholders always invests (i.e., $X_{i}^{b}=0$ ), and thus, there is no debt overhang problem for a firm financed with equity and bank debt exclusively.

In the normal region $\left(X>X_{n}^{b}\right)$, the ODE for the equity value function is simply given by Equation (15) but with $c=0$, subject to the value-matching $E_{b}\left(X_{n}^{b}\right)=(1-q) E_{n b}\left(X_{n}^{b}\right)$ and the no-bubble condition $\lim _{X \rightarrow \infty} E_{b}(X) / X<+\infty$. The optimal renegotiation threshold is given by the smooth-pasting condition $E_{b}^{\prime}\left(X_{n}^{b}\right)=(1-q) E_{n b}^{\prime}\left(X_{n}^{b}\right)$. Similarly, the value of bank debt $B_{n b}(X)$ for $X>X_{n}^{b}$ satisfies the ODE that given by (9) but with $c=0$. Thus, the value functions for the equity value and the bank debt value respectively resemble Equations (16) and (2) with $c=0$ and $\zeta=(1-\alpha)$, where the corresponding

investment and renegotiation thresholds are replaced by $X_{i}^{b}$ and $X_{n}^{b}$, respectively. Finally, shareholders choose the optimal coupon payment $c_{b}^{*}$ to maximize the ex-ante equity value (initial firm value), in that $c_{b}^{*}\left(X_{0}\right)=\arg \max _{b} V_{b}\left(X_{0} ; b\right)$.

\section{$5 \quad$ Model implications}

In this section, we consider important model implications from our quantitative analysis. Sections 5.1 defines the baseline value of the parameters used in our model. Section 5.2 discusses the optimal capital structure decisions for three types of firms issuing only bank debt, only market debt, and a mixture of both, respectively. It further analyses the optimal composition of debt structure, which identifies a substitution effect between bank and market debt issuance. Section 5.3 investigates comparative statics of the optimal ex-post investment, renegotiation, and default policies with varying parameters' value. Section 5.4 considers the debt priority structure and its effects on firm investment (debt overhang) and firm value. Section 5.5 shows the net benefit of issuing a mixture of bank and market debt compared with the bank debt only or market debt only scenarios. Some novel empirical implications observed from our model are summarized in Section 5.6.

\subsection{Parameter calibration and choice}

Following the dynamic capital structure literature, we use the following annualized parameter values for our numerical analysis. The initial level of productivity is normalized to $X_{0}=1$. Similar to Leland (1998), Hackbarth, Rivera and Wong (2019), the risk-free interest rate is $r=5 \%$, the risk-neutral baseline growth 
rate is $\mu=1 \%$, the volatility is $=25 \%$, the effective tax rate is $\tau=20 \%$, and the bankruptcy cost is $\alpha=40 \%$. The shareholders' bargaining power is taken to be $\eta=0.65$. This is consistent with Danis and Gamba (2018) who calibrates a $65 \%$ bargaining power for the shareholders. Finally, we set the incremental productivity growth rate to be $i_{0}=2 \%$, and the investment cost to be $\phi=8$ for productivity growth for the project. More specifically, Table 2 reports the parameter values for the benchmark model and all the parameters take the baseline parameter values unless otherwise stated.

Table 2: Baseline parameter values

\begin{tabular}{lcc}
\hline Variable & Symbol & Value \\
\hline Risk-adjusted growth rate & $\mu$ & $1 \%$ \\
Volatility & $\sigma$ & $25 \%$ \\
Risk-free interest rate & $r$ & $5 \%$ \\
Bank debt coupon rate & $b$ & \\
Market debt coupon rate & $c$ & \\
Effective tax rate & $\tau$ & $20 \%$ \\
Bankruptcy cost rate & $\alpha$ & $40 \%$ \\
Investment cost & $\phi_{h}$ & 8 \\
Productivity growth rate & $i_{0}$ & $2 \%$ \\
Shareholders' bargaining power & $\eta$ & $65 \%$ \\
Initial value of cash flow & $X_{0}$ & 1.00 \\
Renegotiation failure probability & $q$ & $30 \%$ \\
Debt priority & $\zeta$ & 1 \\
\hline
\end{tabular}

\subsection{Optimal market leverage and debt composition}

In this section, we investigate a firm's optimal leverage under three different scenarios that the firm issues a mixture of bank and mark debt, bank debt only, and market debt only, respectively. Overall, the firm has the highest market leverage when issuing a mixture of bank and market debt as indicated in Figure 1. Also, bank debt increases a firm's debt capacity in most of our parameter regions except for the cases with a higher renegotiation friction failure probability or a higher effective tax rate. This is straightforward as the renegotiation friction indeed disincentivizes the bank debt issuance and bank debt has less tax shield benefit as its coupon might be reduced due to renegotiation.

Consistent with the standard strand of the trade-off capital structure literature, e.g. Leland (1994, 1998), Figure 1 shows a decline (rise) in optimal leverage with the bankruptcy cost (effective tax rate). Consistent with empirical evidence that risky small firms use privately placed debt almost exclusively (Blackwell and Kidwell 1988, Denis and Mihov 2003), Panel B of Figure 1 shows that the capacity of private bank debt increases with asset volatility. This is mainly because bank debt substitutes more market debt when a firm's cash flow is riskier to avoid bankruptcy inefficiency. 
Panel A

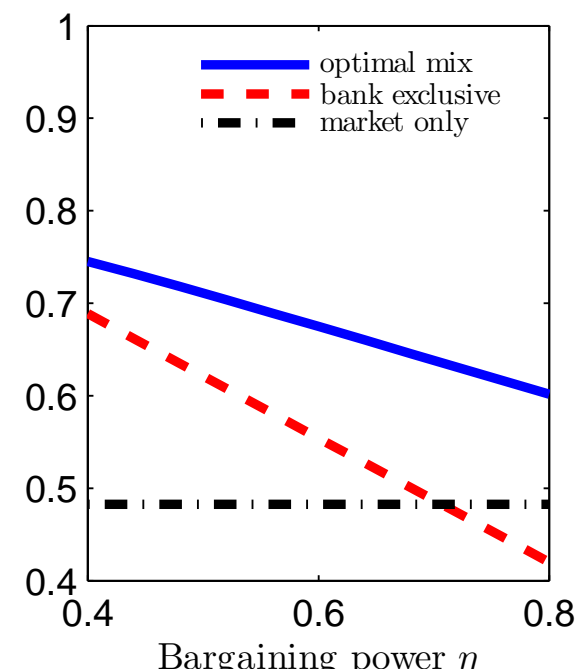

Bargaining power $\eta$

Panel D

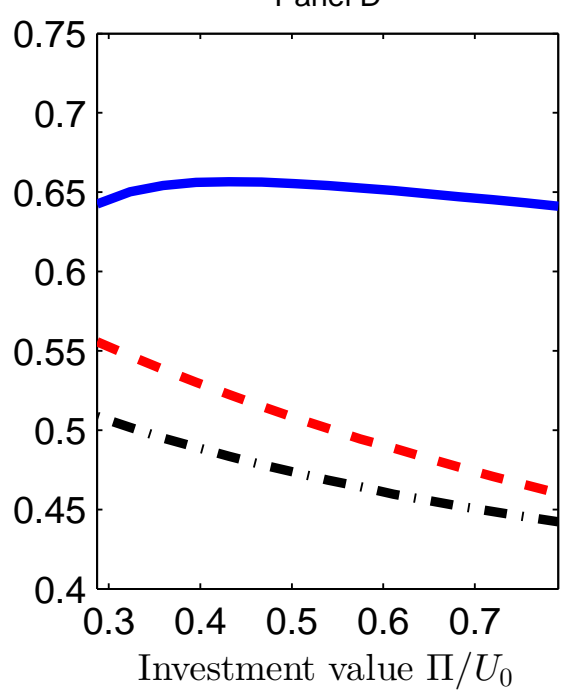

Panel B

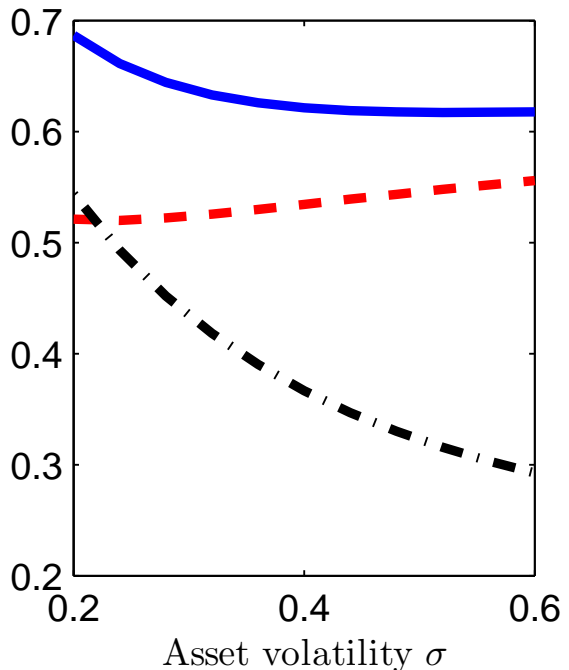

Panel E

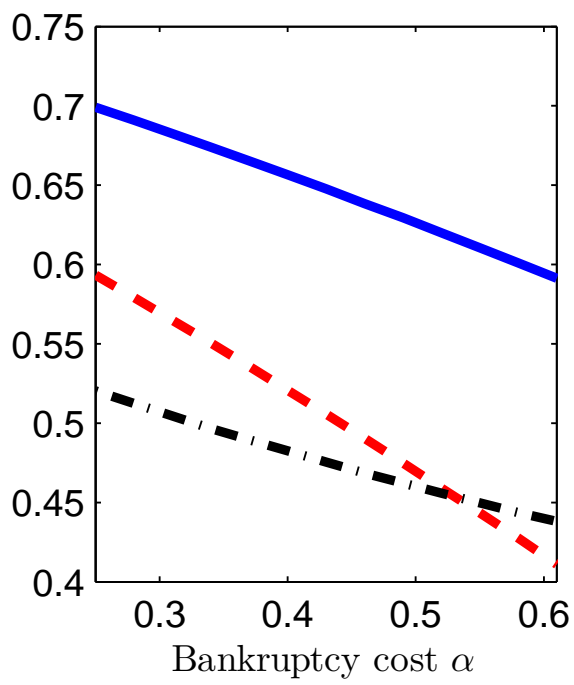

Panel C

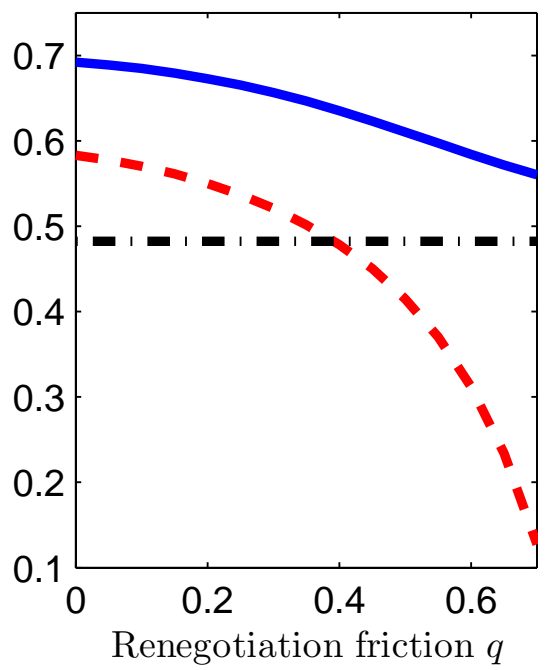

Panel F

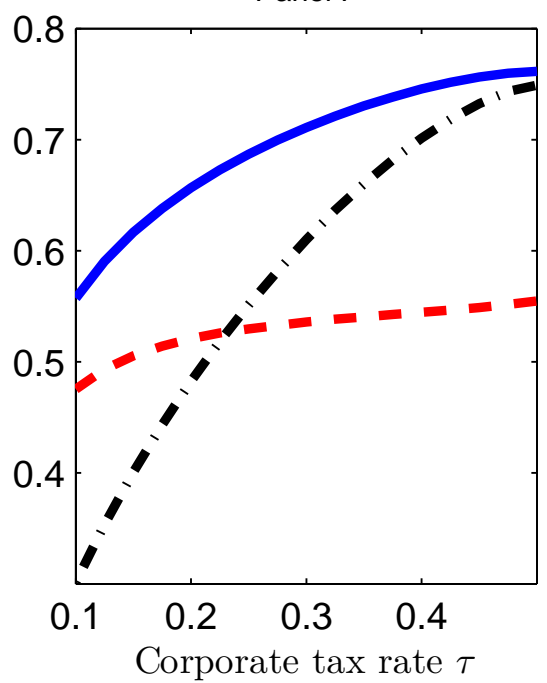

Figure 1: The comparative statics of the firm's optimal market leverage under three different types of debt structure: i.e. the mix of bank and market debt, bank debt only, and market debt only, respectively.

Figure 2 shows the optimal composition of bank and market debt for different values of parameters. In general, there exists a substitution effect between bank debt and market debt. For example, firms tend to substitute bank debt with market debt when shareholders have higher bargaining power, the renegotiation failure probability increases, the investment value is bigger, and the bankruptcy cost is larger, as reflected in Figure 2 Panel A, C, D, and E, respectively. This is mainly because bank debt loses its edge against market debt when shareholders could extract more from creditors and the renegotiation friction is severe. Interestingly, bank debt issuance might even speed the bankruptcy process should there be an extremely high negotiation failure probability as we assume the firm enters into liquidation once the renegotiation fails. 

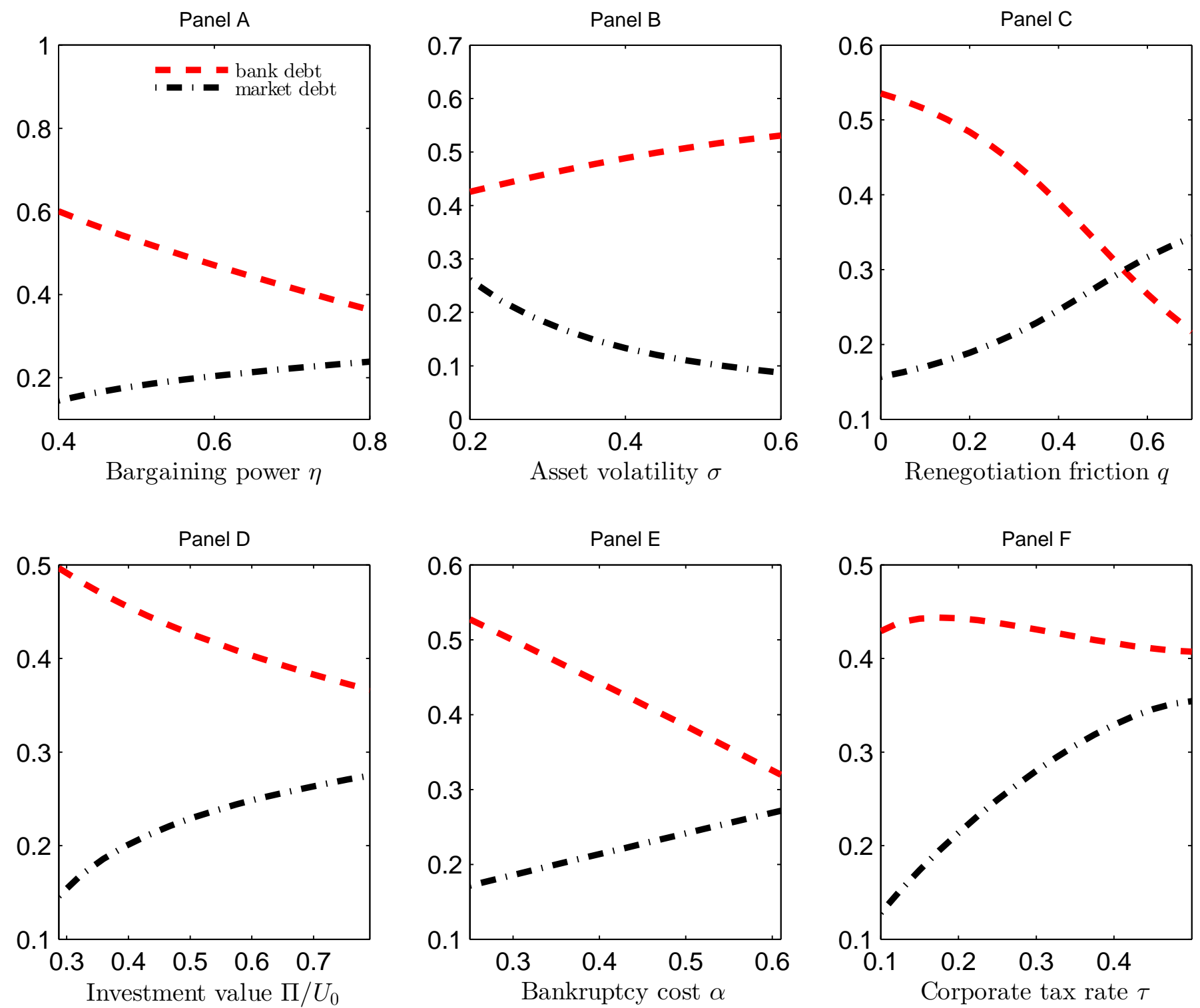

Figure 2: The comparative statics of the optimal debt composition when the firm is financed with a mixture of bank and market debt, and the bank debt is granted senior to the market debt.

\subsection{Optimal ex-post policies: investment, renegotiation and default}

Figure 3 illustrates ex-post investment, renegotiation and default policies under two different types of firm debt structures. There are several implications from our results.

First, shareholders' bargaining power has a non-monotonic effect on the ex-post default policy. On one hand, all else equal, stronger shareholders (with higher bargaining power) delay bankruptcy as they are able to extract more renegotiation surplus in a private workout. On the other hand, market debt substitutes more bank debt when shareholders have stronger bargaining power, leading to a higher default threshold. In our model, stronger shareholders default earlier as the negative effect from substitution dominates the positive 
Panel A

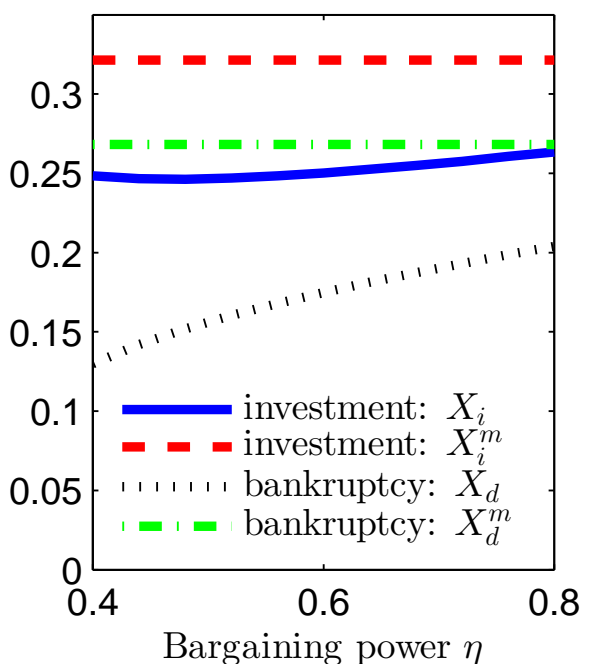

Bargaining power $\eta$

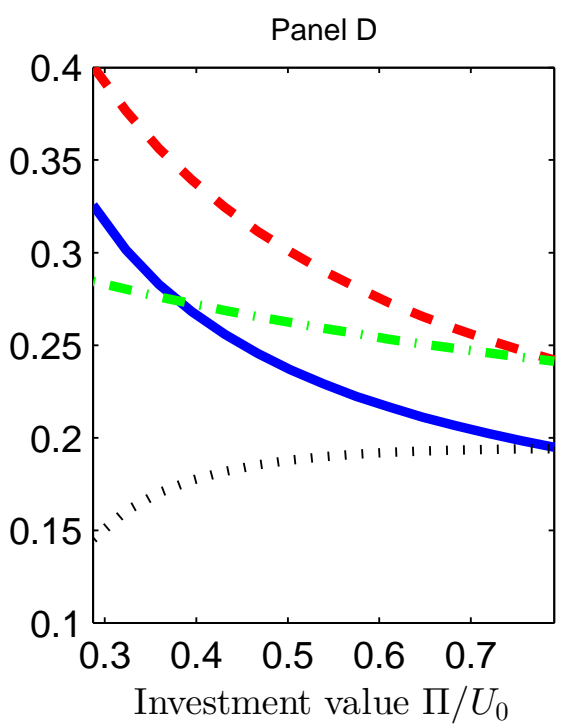

Panel B

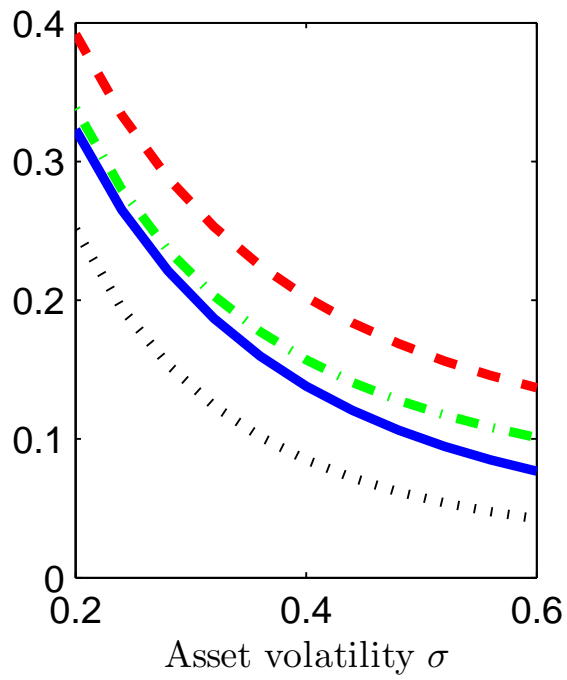

Panel E

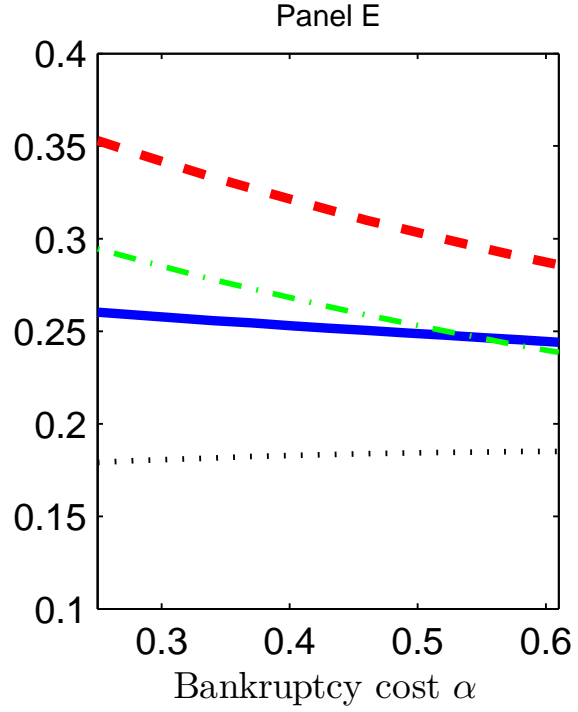

Panel C

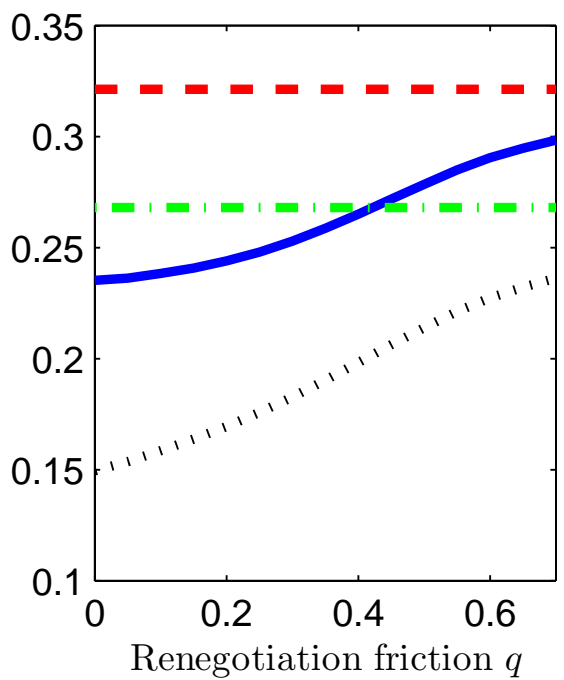

Panel F

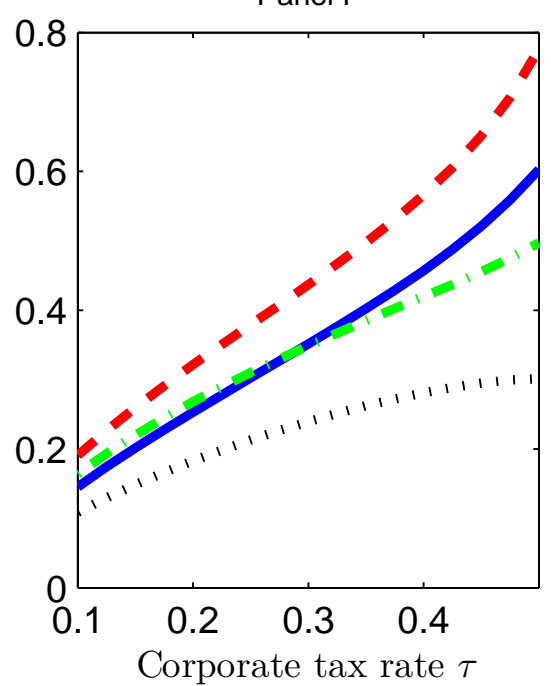

Figure 3: The comparative statics of the optimal ex-post investment and default policies for firms with either a mixed debt structure or a market debt only structure. The blue solid line (red dashed line) plots the investment threshold of a firm with mixed debt composition ( market debt only financing). The black dotted line (green dash-dotted line) plots the default threshold for a firm with mixed debt financing ( market debt only structure).

one from the surplus extraction, which is consistent with the empirical evidence found in Colonnello, Efing and Zucchi (2019).

Second, firms issuing bank debt along with market debt accelerate corporate investment and the bank debt issuance on average mitigates ex-post debt overhang, the effect of which is much stronger (the gap between the blue solid line and the red dash line is wider in Figure 3) when the negotiation failure rate is lower (Panel C), the bankruptcy cost is smaller (Panel E), and the corporate tax rate is higher (Panel F). 
Third, Panel B of Figure 3 illustrates the monotonic effect of asset volatility on firm investment and default polices. The bankruptcy threshold declines with asset volatility due to the real option value of waiting, as noted in Sundaresan, Wang and Yang (2015), Wong and Yu (2020). Also, bank debt substitutes market debt more when asset volatility is higher (the equity feature or bank debt due to renegotiation), delaying the default trigger. Consistent with the standard real option theory such as McDonald and Siegel (1986), a firm accelerates investment when its asset volatility is higher as its investment threshold monotonically decreases with asset volatility.

Fourth, shareholders impede firm investment (future asset growth) as a result of debt overhang when the investment value is lower (Panel D), the bankruptcy cost is smaller (Panel E), and the corporate tax rate is higher (Panel F). It is straightforward that a firm is less likely to invest a low-value project. As a firm trades the debt tax shield benefit off its bankruptcy cost when issuing debt, it will optimally issue more debt when the bankruptcy cost is smaller or the tax rate is higher. In such cases, creditors will get most of the future investment value due to debt overhang, which in turn reduces shareholders' incentive to investment.
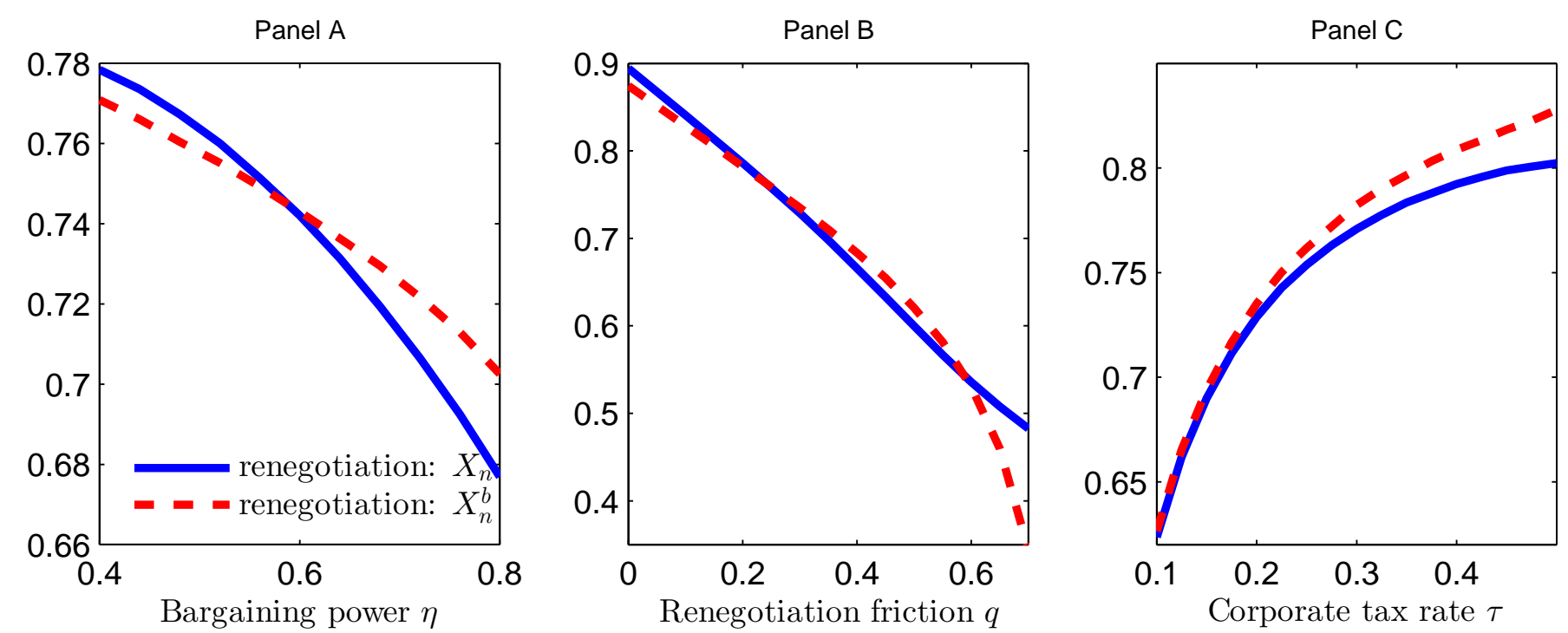

Figure 4: The comparative statics of the ex-post renegotiation threshold for firms with either a mixed debt structure or a bank debt only structure.

Fifth, shareholders have less incentive to renegotiate the bank debt contract if the renegotiation friction is higher, which is consistent with the economic intuition that higher renegotiation friction significantly reduces the value of the default option. Also, higher tax rates increase shareholders' renegotiation incentive as the bank debt holders will share less option value of expansion (higher investment thresholds) in such scenarios. Consistent with the value of waiting (real option) theory as in McDonald and Siegel (1986), Wong and Yu (2020), stronger shareholders will delay debt renegotiation as they are able to extract more renegotiation surplus. 


\subsection{Debt structure, debt overhang and firm valuation}

We now turn to investigate how a firm's debt structure and its priority structure affect its ex-post investment decisions and the firm valuation. To be specific, we first illustrate the effects of varying debt compositions on firm investment (firm valuation) in Figure 5 (Figure 6) under three alternative priority structures (namely, senior bank debt, senior market debt, and equal priority) ${ }^{2}$. Then, we summarize the key results of ex-post policies, optimal coupon payments, and the value of corporate securities under each type of these priority structures in Table 3. Finally, inspired by Hackbarth and Mauer (2012), we extend our benchmark model by considering arbitrary priority structure and the effects of which on ex-post policies, leverage, and firm valuation are presented in Figure 7- 8.

Figure 5 shows the ex-post investment policy as a function of bank coupon and market coupon payments for a firm with a mixed debt issuance placing bank debt as senior (Panel A), junior (Panel B), and equal priority (Panel C), respectively. In general, the higher level of existing debt, particularly for market debt, in place impedes firm investment as expected. Interestingly, given a constant high level of market debt in place, issuing more bank debt accelerates firm investment when bank debt is granted senior, as indicated in Panel A of Figure 5. This is because the renegotiation feature of bank debt allows shareholders to extract part of the renegotiation surplus from bank debt creditors, which, to some extent, mitigates the debt overhang effect.
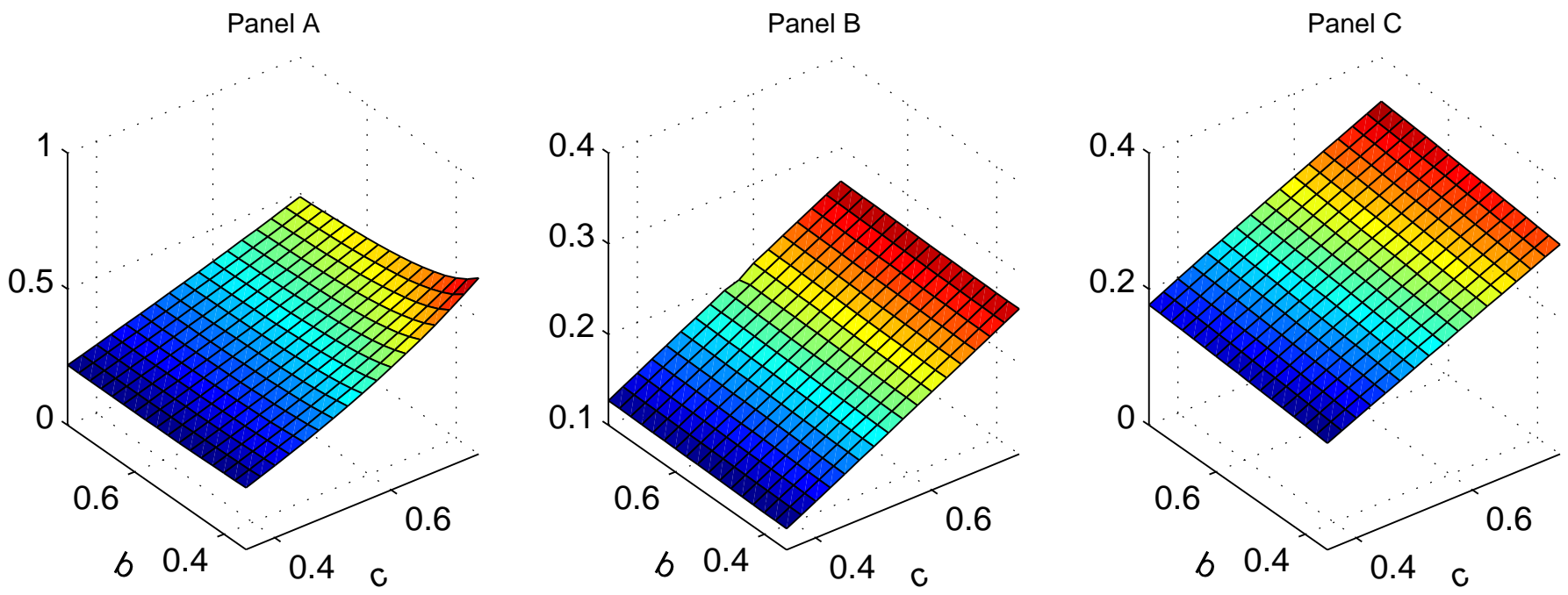

Figure 5: The ex-post investment policy $X_{i}$ as a function of promised coupon payments to the bank $(b)$ and to the market $(c)$ when the bank debt is senior (Panel A), junior(Panel B), and equal (Panel C) to the market debt, respectively.

Figure 6 illustrates the effect of debt structure on firm valuation under three alternative priority structures. Generally speaking, the firm value is much more sensitive to its junior debt's value and firms optimally issue more senior debt (either bank or market debt), as indicated in Panel A and B of Figure 6. Consis-

\footnotetext{
${ }^{2}$ See Broadie and Chernov (2007), Hackbarth and Mauer (2012) among others for the discussion of alternative debt priority structures.
} 
tent with the empirical evidence provided by Rauh and Sufi (2010) that "low-credit-quality firms have a multi-tiered capital structure consisting of both secured bank debt with tight covenants and subordinated non-bank debt with loose covenants", our numerical results show that firms with a mixed of bank and market debt placing bank debt as senior have the highest value compared to other priority structures. Table 3 also verifies this result that the firm with a mixed debt structure consisting senior bank debt and junior market debt has the highest firm value of $28.38,2.5 \%$ higher compared to the opposite case (27.70).

Panel A

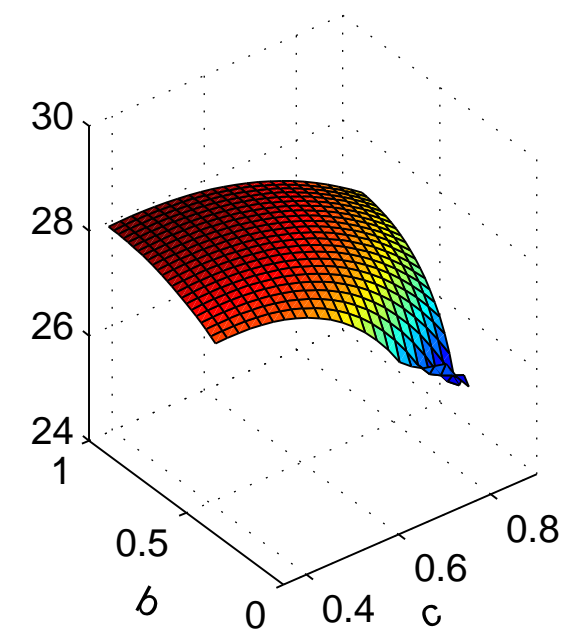

Panel B

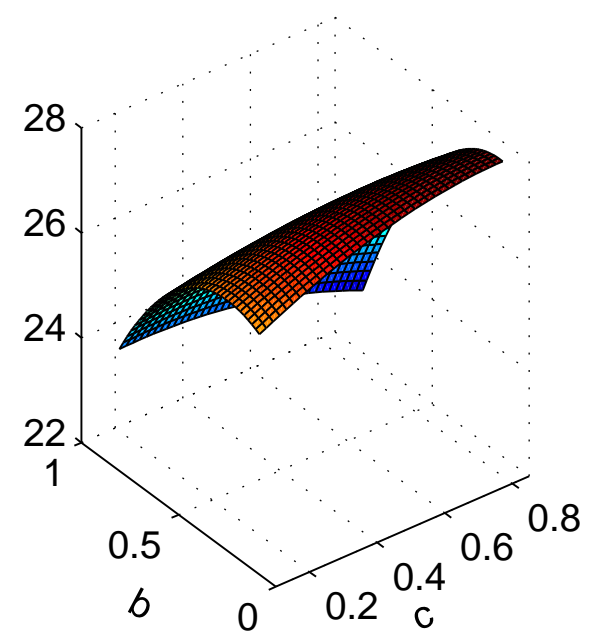

Panel C

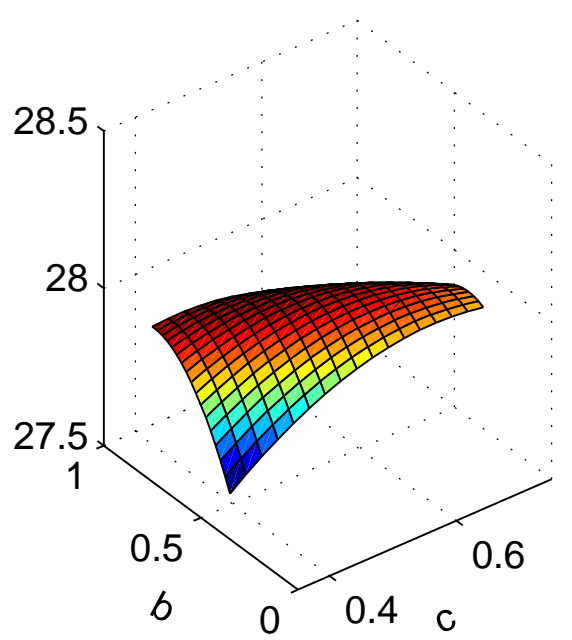

Figure 6: The firm value as a function of promised coupon payments to the bank $(b)$ and to the market $(c)$ when the bank debt is (Panel A), junior(Panel B), and equal (Panel C) to the market debt, respectively. Note that there exists an interior firm value optimum for both classes of debt under each priority structure, i.e. in Panel A, $V\left(b^{*}, c^{*}\right)=28.38$, where $b^{*}=0.88$ and $c^{*}=0.40$; in Panel $\mathrm{B}, V\left(b^{*}, c^{*}\right)=27.70$, where $b^{*}=0.14$ and $c^{*}=0.84$; and in Panel C, $V\left(b^{*}, c^{*}\right)=28.01$, where $b^{*}=0.67$ and $c^{*}=0.45$.

Table 3: Ex-post policies, optimal leverage, and firm valuation for firms issuing a mixed of band and market debt under three alternative priority structures.

\begin{tabular}{lrrrrrrrrr}
\hline Priority Structure & $X_{d}$ & $X_{i}$ & $X_{n}$ & $b^{*}$ & $c^{*}$ & $L_{b}$ & $L_{c}$ & $E\left(X_{0}\right)$ & $V\left(X_{0}\right)$ \\
\hline Bank debt is senior $(\zeta=1)$ & 0.18 & 0.25 & 0.73 & 0.88 & 0.40 & $44.13 \%$ & $22.29 \%$ & 9.53 & 28.38 \\
Equal priority $\left(\zeta=\frac{b}{b+c}\right)$ & 0.16 & 0.21 & 0.76 & 0.67 & 0.45 & $34.39 \%$ & $26.02 \%$ & 11.09 & 28.01 \\
Market debt is senior $(\zeta=0)$ & 0.24 & 0.30 & 0.62 & 0.14 & 0.84 & $8.31 \%$ & $48.62 \%$ & 11.93 & 27.70 \\
\hline
\end{tabular}

Table 3 also reports optimal ex-post investment, default, and renegotiation policies for three alternative priority structures. The priority structure, $\zeta^{*}$, is endogenously determined by the optimal coupon payments, $b^{*}$ and $c^{*}$, given than $\zeta \equiv \frac{b}{b+c}$ for the equal priority scenario. We find that firms are more (less) likely to invest (default) and renegotiate under the equal priority structure.

Now we consider a general case of an arbitrary priority structure $\left(\zeta \in\left[\begin{array}{ll}0 & 1\end{array}\right]\right)$. To be specific, given 
an arbitrary priority structure, $\zeta$, we investigate how the priority structure affects firms' financing and real investment decisions. Figure 7 presents the monotonic effects of priority structure $(\zeta)$ on optimal capital structure, the net benefit of mixed debt financing, and firm valuation. Firms tend to have higher leverages, the greater benefit of mixed debt financing, and larger firm values when bank debt is more secured (a higher $\zeta)$, consistent with Rauh and Sufi (2010). Regarding the ex-post policies, firms, on average, accelerate investment, delay bankruptcy, and speed debt renegotiation when bank debt priority is higher, as indicated in Figure 8.
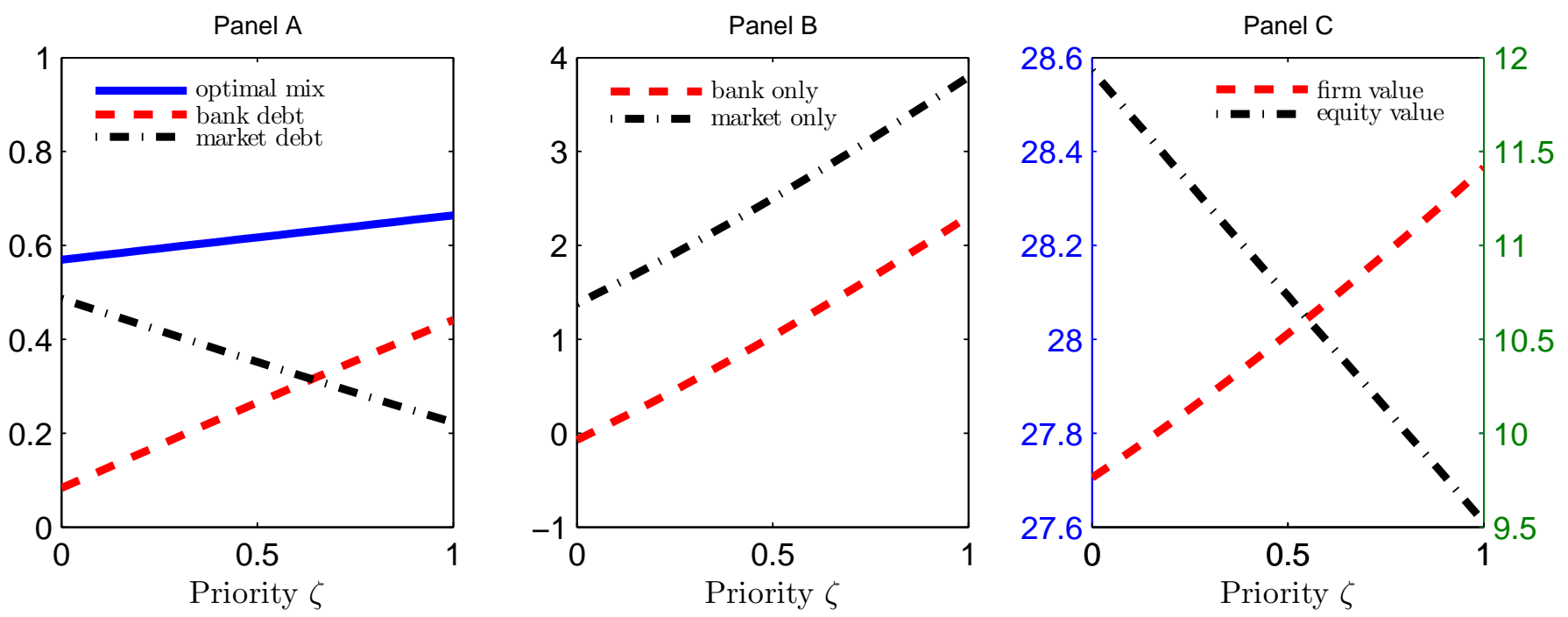

Figure 7: The effects of debt priority structure on the optimal debt composition (Panel A), the net benefit of mixed debt financing (Panel B), and the value of corporate securities (Panel C). The net benefit of mixed debt financing is reported in percentage

\subsection{The net benefit of mixed debt financing}

In this subsection, we aim to investigate the market situations in which a firm with mixed debt financing is more likely to achieve benefits. To be more specific, The net debt benefit of mixed debt financing over exclusive bank debt financing (exclusive market debt financing) is defined as $\frac{V-V_{b}}{V_{b}} \times 100 \%\left(\frac{V-V_{c}}{V_{c}} \times 100 \%\right)$, where $V, V_{b}$, and $V_{c}$ is firm value with optimal mixed debt financing, exclusive bank debt financing, and exclusive market debt financing, respectively. Our model provides an investment-based explanation for the observed fact that why many corporations choose mixed debt financing (Rauh and Sufi 2010). Figure 9 shows the comparative statics of the net benefit of mixed debt financing for varying parameter values. In all simulated scenarios, firms with mixed debt financing outperform other firms with either only bank debt or only market debt. The increase of firm valuation could be as large as over $30 \%$ for a higher tax rate (Panel $\mathrm{F}$ of Figure 9). In general, our model indicates mixed debt financing could enhance firm value by $5 \%$ to $10 \%$.

We also find, in most cases, bank debt exclusive financing structure dominates market debt only one, reflecting an edge of bank debt from the renegotiation. Market debt exclusive structure dominates only when there is a higher shareholders' bargaining power, larger renegotiation friction, or a higher tax rate. 

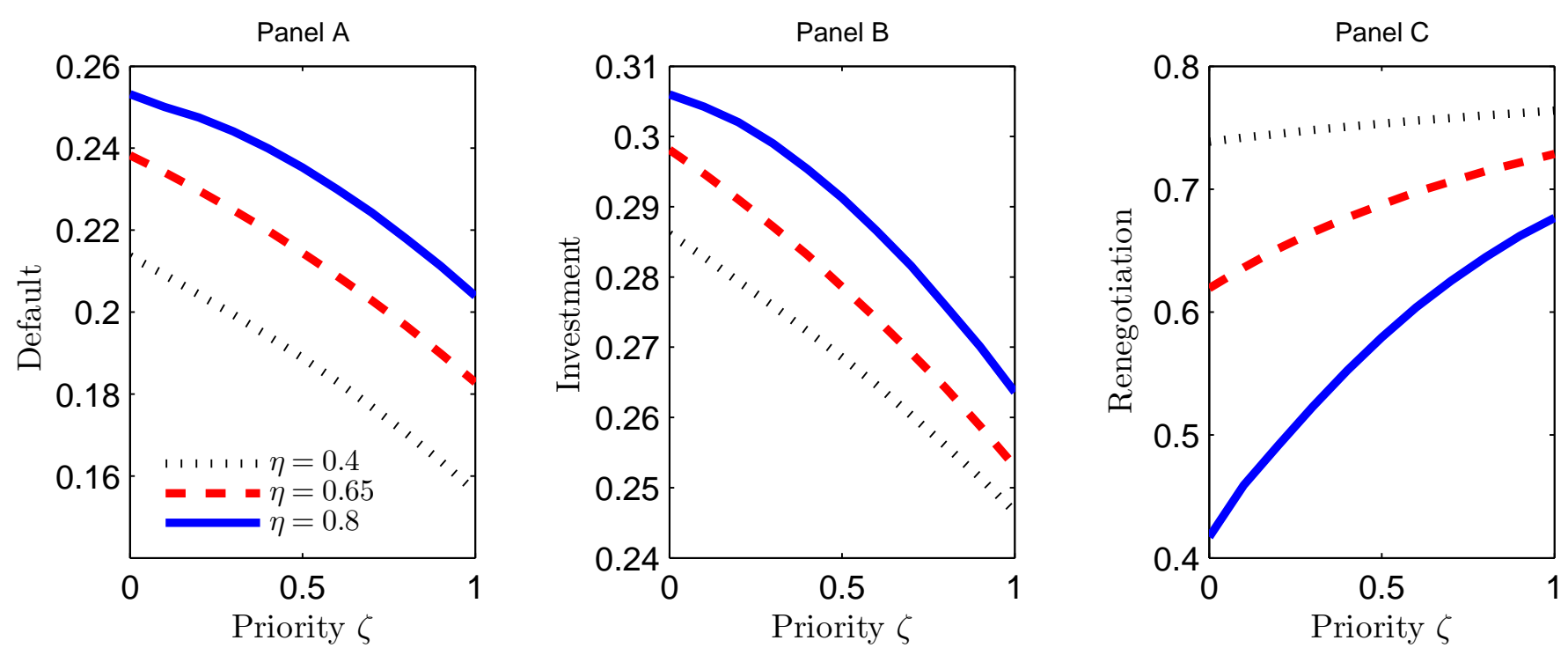

Figure 8: The effects of debt priority structure on the optimal ex-post default policy (Panel A), investment policy (Panel B), and firm valuation (Panel C) with three levels of shareholders' bargaining power.

This is because, in such scenarios, market debt is more favorable as it avoids renegotiation failure (higher renegotiation friction) and has greater tax shield benefit (higher tax rate).

\subsection{Empirical implications}

Our model provides novel empirical implications regarding how debt renegotiation and its frictions such as shareholders' bargaining power and the failure probability of renegotiation affect corporate optimal financing debt composition.

Observation 1: Bank debt dominates market debt in most cases because of its ability to avoid inefficient bankruptcy via renegotiation. The result turns around as bank debt loses its edge when the renegotiation friction is higher (either a higher shareholders' bargaining power or a higher probability of renegotiation failure) or the tax shield benefit is larger for market debt.

Consistent with Rauh and Sufi (2010), Colla, Ippolito and Li (2013), Crouzet (2017) among others, the model also matches the stylized fact that firms tend to use multi-tier debts to finance corporate investment.

Observation 2: The benefit of mixed debt financing is significantly large (a firm valuation boosts between 5\%-10\% as indicated in Figure 9) compared to either bank debt exclusive or market debt exclusive debt structures. Firms optimal trade the benefit of debt renegotiation off its frictions when making financing decisions.

In the framework of our model, we are able to investigate the intertwined effect of corporate heterogeneous debt financing and investment decisions on firm valuation.

Observation 3: The issuance of bank debt along with market debt accelerates firm investment, which mitigates the ex-post debt overhang effect. This negative effect is much stronger when the renegotiation failure probability or the bankruptcy cost is lower.

Observation 4: Our model predicts that priority structure $(\zeta)$ has a monotonic positive effect on firms' 
Panel A

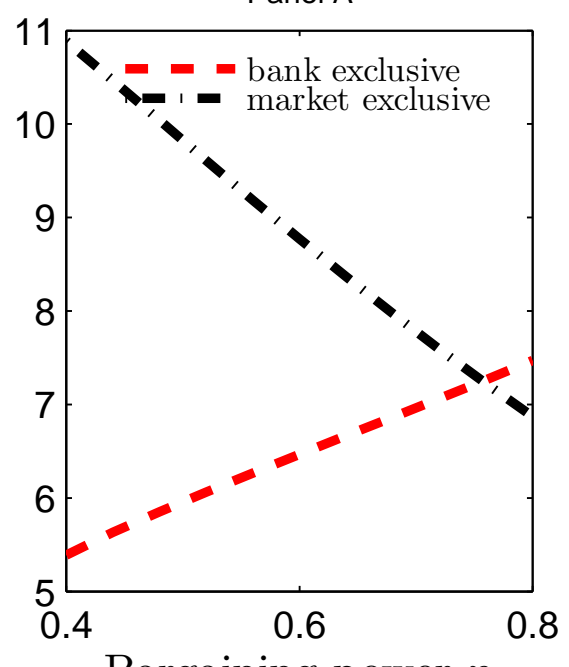

Bargaining power $\eta$

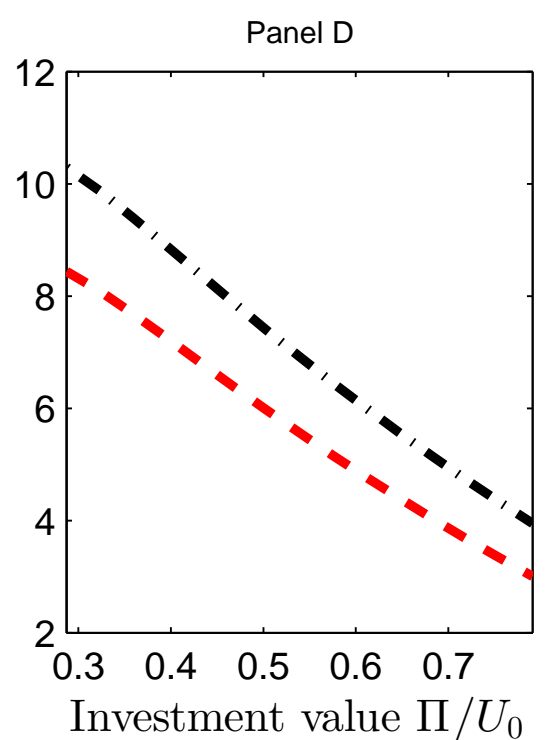

Panel B

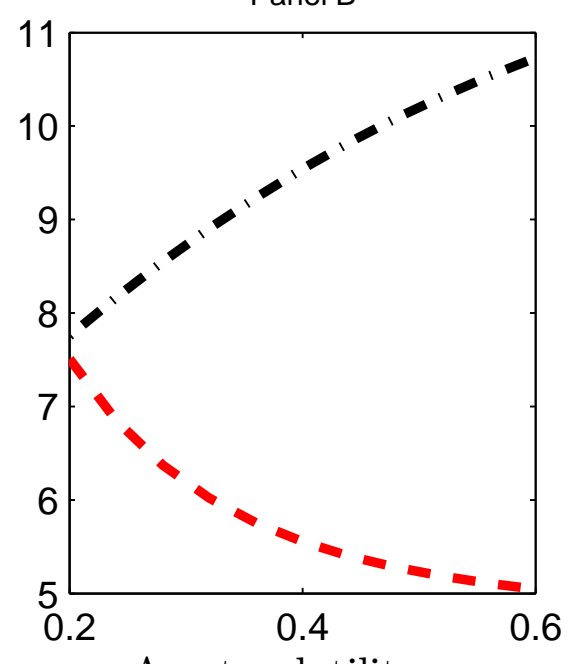

Asset volatility $\sigma$

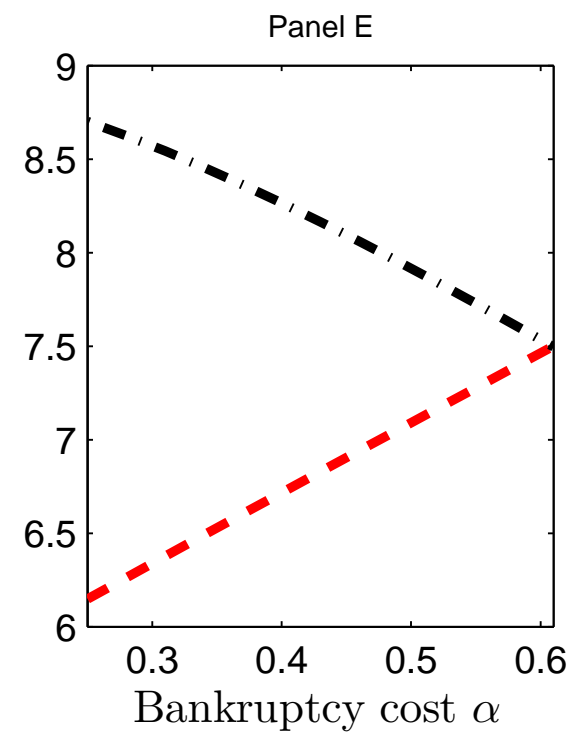

Panel C

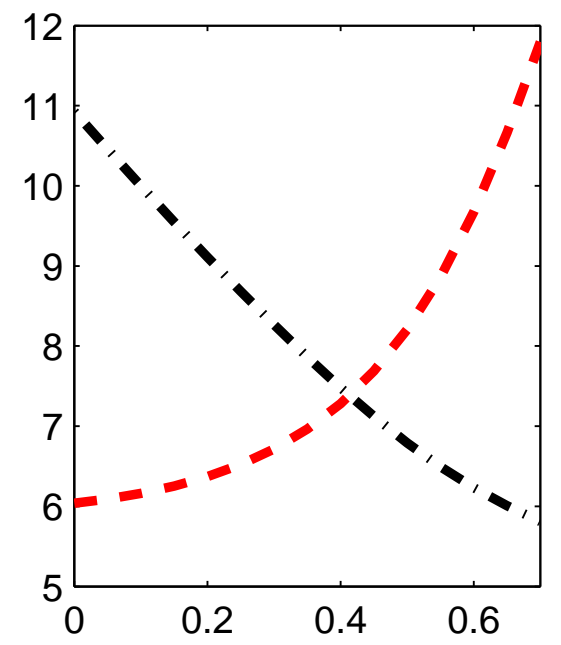

Renegotiation friction $q$

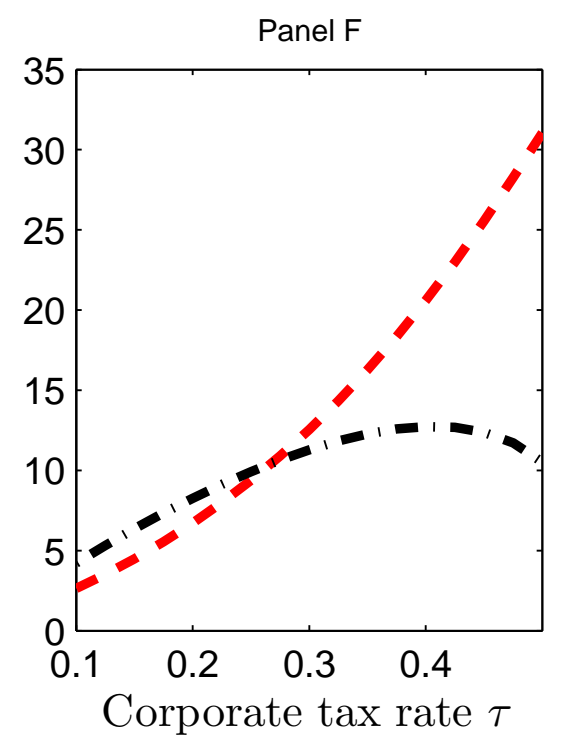

Figure 9: The comparative statics of the net benefit of mixed debt financing compared to the bank debt only and the market debt only scenarios. The net benefit of mixed debt financing is reported in percentage.

optimal capital structure, the net benefit of mixed debt financing, and firm valuation, the effect of which is much stronger for weaker shareholders (with lower bargaining power).

\section{Conclusion}

Most extant theoretical literature on strategic debt service, see Hackbarth, Hennessy and Leland (2007), Hackbarth and Mauer (2012), Morellec, Valta and Zhdanov (2015), Shibata and Nishihara (2015a,b) among others, ignore one of the most important facts that firms simultaneously use bank and market debt (Rauh and Sufi 2010). The main contribution of this paper is that we integrate the two strands of literature, en- 
dogenous investment and mixed debt structure, by developing a dynamic trade-off model that simultaneously incorporates both flexible investment opportunities and heterogeneous (mixed) debt financing. We study the impact of the optimal debt and priority structure on the intertwined corporate financing and investment decisions in a dynamic trade-off model, where the firm simultaneously uses bank and market debt for financing. Private bank debt is renegotiable during financial distress, thus it avoids inefficient and costly bankruptcy losses should the renegotiation be successful. However, bank debt does not always dominate market debt as there exists renegotiation friction specifying a probability of renegotiation failure. By considering both the endogenous investment and debt heterogeneity in a parsimonious pricing model, we shed light on the interactions between mixed debt financing and investment decisions when shareholders optimally choose growth option exercise, renegotiation and default policies and the firm's optimal capital structure are driven by renegotiation cost, bankruptcy cost, tax shield benefit and investment benefits.

We have four important results with respect of the impact of he debt structure and its priority structure on corporate investment and firm valuation. First, bank debt dominates market debt in most cases because of its ability to avoid inefficient bankruptcy via renegotiation. The result turns around as bank debt loses its edge when the renegotiation friction is higher (either a higher shareholders' bargaining power or a higher probability of renegotiation failure) or the tax shield benefit is larger for market debt. Second, the benefit of optimal mixed debt financing is significantly large (a firm valuation boosts between 5\%-10\%) compared to either bank debt exclusive or market debt exclusive debt structures. Firms optimal trade the benefit of debt renegotiation off its frictions when making financing decisions. Third, The issuance of bank debt along with market debt accelerates firm investment, which mitigates the ex-post debt overhang effect. This negative effect is much stronger when the renegotiation failure probability or the bankruptcy cost is lower (i.e. bank debt has the largest edge over market debt). However, shareholders' bargaining power, renegotiation friction, growth potential, and bankruptcy costs limit bank debt capacity. Fourth, debt priority structure has a monotonic positive effect on firms' optimal capital structure, the net benefit of mixed debt financing, and firm valuation, the effect of which is much stronger for weaker shareholders, therefore, it would be optimal to place bank debt as senior for firm value maximization. 


\section{Appendix A Defined constants in Propositions}

The constants $G_{1}, G_{2}, G_{3}, G_{4}$ and $G_{5}$ are given by

$$
\begin{aligned}
& G_{1}=m_{1} X_{n}^{-\gamma_{1}}+(1-q)\left(G_{2}+G_{3} X_{n}^{\gamma_{2}-\gamma_{1}}\right), \\
& G_{2}=m_{3} X_{i}^{-\gamma_{1}}+G_{4} X_{i}^{\beta_{1}-\gamma_{1}}+G_{5} X_{i}^{\beta_{2}-\gamma_{1}}-G_{3} X_{i}^{\gamma_{2}-\gamma_{1}}, \\
& G_{3}=\frac{m_{2}-\gamma_{1} m_{1}}{\left(\gamma_{1}-\gamma_{2}\right)(1-q) X_{n}^{\gamma_{2}}}, \\
& G_{4}=\frac{X_{i}^{\beta_{2}}\left(\gamma_{1}-\beta_{2}\right) m_{4}-X_{d}^{\beta_{2}}\left[m_{3}-\gamma_{1} m_{3}-G_{3}\left(\gamma_{2}-\gamma_{1}\right) X_{i}^{\gamma_{2}}\right]}{\left(\gamma_{1}-\beta_{2}\right) X_{i}^{\beta_{2}} X_{d}^{\beta_{1}}-\left(\gamma_{1}-\beta_{1}\right) X_{i}^{\beta_{1}} X_{d}^{\beta_{2}}}, \\
& G_{5}=\frac{X_{d}^{\beta_{1}}\left[m_{3}-\gamma_{1} m_{3}-G_{3}\left(\gamma_{2}-\gamma_{1}\right) X_{i}^{\gamma_{2}}\right]-X_{i}^{\beta_{1}}\left(\gamma_{1}-\beta_{1}\right) m_{4}}{\left(\gamma_{1}-\beta_{2}\right) X_{i}^{\beta_{2}} X_{d}^{\beta_{1}}-\left(\gamma_{1}-\beta_{1}\right) X_{i}^{\beta_{1}} X_{d}^{\beta_{2}}},
\end{aligned}
$$

where the constants $\gamma_{1}, \gamma_{2}, \beta_{1}, \beta_{2}, m_{1}, m_{2}, m_{3}$ and $m_{4}$ are given by

$$
\begin{aligned}
& \gamma_{1}=-\frac{1}{\sigma^{2}}\left[\left(\mu+i-\frac{\sigma^{2}}{2}\right)+\sqrt{\left(\mu+i-\frac{\sigma^{2}}{2}\right)^{2}+2 r \sigma^{2}}\right], \\
& \gamma_{2}=-\frac{1}{\sigma^{2}}\left[\left(\mu+i-\frac{\sigma^{2}}{2}\right)-\sqrt{\left(\mu+i-\frac{\sigma^{2}}{2}\right)^{2}+2 r \sigma^{2}}\right], \\
& \beta_{1}=-\frac{1}{\sigma^{2}}\left[\left(\mu-\frac{\sigma^{2}}{2}\right)+\sqrt{\left(\mu-\frac{\sigma^{2}}{2}\right)^{2}+2 r \sigma^{2}}\right], \\
& \beta_{2}=-\frac{1}{\sigma^{2}}\left[\left(\mu-\frac{\sigma^{2}}{2}\right)-\sqrt{\left(\mu-\frac{\sigma^{2}}{2}\right)^{2}+2 r \sigma^{2}}\right] \\
& m_{1}=q\left[L\left(X_{n}\right)-U_{i} X_{n}\right]-\frac{\tau(q c+b)}{r}, \\
& m_{2}=q\left[L^{\prime}\left(X_{n}\right) X_{n}-U_{i} X_{n}\right] \\
& m_{3}=U_{0} X_{i}-U_{i} X_{i}, \\
& m_{4}=-U_{0} X_{d}-\frac{\tau c}{r} .
\end{aligned}
$$

The constants $A_{1}, A_{2}, A_{3}, A_{4}$ and $A_{5}$ are given as follows

$$
\begin{aligned}
& A_{1}=q\left((1-\zeta) L\left(X_{n}\right)-\frac{c}{r}\right) X_{n}^{-\gamma_{1}}+(1-q)\left(A_{2}+A_{3} X_{n}^{\gamma_{2}-\gamma_{1}}\right), \\
& A_{2}=A_{4} X_{i}^{\beta_{1}-\gamma_{1}}+A_{5} X_{i}^{\beta_{2}-\gamma_{1}}-A_{3} X_{i}^{\gamma_{2}-\gamma_{1}} \\
& A_{3}=\frac{q(1-\zeta)(1-\alpha) U_{0} X_{n}-q \gamma_{1}\left[(1-\zeta) L\left(X_{n}\right)-c / r\right]}{\left(\gamma_{1}-\gamma_{2}\right) X_{n}^{\gamma_{2}}}, \\
& A_{4}=\frac{\left(\gamma_{1}-\beta_{2}\right)\left[(1-\zeta) L\left(X_{d}\right)-c / r\right] X_{i}^{\beta_{2}}+A_{3}\left(\gamma_{2}-\gamma_{1}\right) X_{i}^{\gamma_{2}} X_{d}^{\beta_{2}}}{\left(\gamma_{1}-\beta_{2}\right) X_{i}^{\beta_{2}} X_{d}^{\beta_{1}}-\left(\gamma_{1}-\beta_{1}\right) X_{i}^{\beta_{1}} X_{d}^{\beta_{2}}} \\
& A_{5}=\frac{A_{3}\left(\gamma_{1}-\gamma_{2}\right) X_{i}^{\gamma_{2}} X_{d}^{\beta_{1}}-\left(\gamma_{1}-\beta_{1}\right)\left[(1-\zeta) L\left(X_{d}\right)-c / r\right] X_{i}^{\beta_{1}}}{\left(\gamma_{1}-\beta_{2}\right) X_{i}^{\beta_{2}} X_{d}^{\beta_{1}}-\left(\gamma_{1}-\beta_{1}\right) X_{i}^{\beta_{1}} X_{d}^{\beta_{2}}},
\end{aligned}
$$


The constants $C_{1}, C_{2}$ and $C_{3}$ are given by

$$
\begin{aligned}
& C_{1}=\left(U_{0}-U_{i}\right)\left(X_{i}^{c}\right)^{1-\gamma_{1}}+C_{2}\left(X_{i}^{c}\right)^{\beta_{1}-\gamma_{1}}+C_{3}\left(X_{i}^{c}\right)^{\beta_{2}-\gamma_{1}} \\
& C_{2}=\frac{\left(1-\gamma_{1}\right)\left(U_{0}-U_{i}\right) X_{i}^{c}\left(X_{d}^{c}\right)^{\beta_{2}}-\left(U_{0} X_{d}^{c}-(1-\tau) c / r\right)\left(\beta_{2}-\gamma_{1}\right)\left(X_{i}^{c}\right)^{\beta_{2}}}{\left(\beta_{2}-\gamma_{1}\right)\left(X_{i}^{c}\right)^{\beta_{2}}\left(X_{d}^{c}\right)^{\beta_{1}}-\left(\beta_{1}-\gamma_{1}\right)\left(X_{i}^{c}\right)^{\beta_{1}}\left(X_{d}^{c}\right)^{\beta_{2}}} \\
& C_{3}=\frac{\left(U_{0} X_{d}^{c}-(1-\tau) c / r\right)\left(\beta_{1}-\gamma_{1}\right)\left(X_{i}^{c}\right)^{\beta_{1}}-\left(1-\gamma_{1}\right)\left(U_{0}-U_{i}\right) X_{i}^{c}\left(X_{d}^{c}\right)^{\beta_{1}}}{\left(\beta_{2}-\gamma_{1}\right)\left(X_{i}^{c}\right)^{\beta_{2}}\left(X_{d}^{c}\right)^{\beta_{1}}-\left(\beta_{1}-\gamma_{1}\right)\left(X_{i}^{c}\right)^{\beta_{1}}\left(X_{d}^{c}\right)^{\beta_{2}}}
\end{aligned}
$$

The constants $F_{1}, F_{2}$, and $F_{3}$ are given by

$$
\begin{aligned}
& F_{1}=F_{2}\left(X_{i}^{c}\right)^{\beta_{1}-\gamma_{1}}+F_{3}\left(X_{i}^{c}\right)^{\beta_{2}-\gamma_{1}} \\
& F_{2}=\frac{\left(\beta_{2}-\gamma_{1}\right)\left(X_{i}^{c}\right)^{\beta_{2}}\left(L\left(X_{d}^{c}\right)-\frac{c}{r}\right)}{\left(\beta_{2}-\gamma_{1}\right)\left(X_{i}^{c}\right)^{\beta_{2}}\left(X_{d}^{c}\right)^{\beta_{1}}-\left(\beta_{1}-\gamma_{1}\right)\left(X_{i}^{c}\right)^{\beta_{1}}\left(X_{d}^{c}\right)^{\beta_{2}}}, \\
& F_{3}=\frac{\left(\gamma_{1}-\beta_{1}\right)\left(X_{i}^{c}\right)^{\beta_{1}}\left(L\left(X_{d}^{c}\right)-\frac{c}{r}\right)}{\left(\beta_{2}-\gamma_{1}\right)\left(X_{i}^{c}\right)^{\beta_{2}}\left(X_{d}^{c}\right)^{\beta_{1}}-\left(\beta_{1}-\gamma_{1}\right)\left(X_{i}^{c}\right)^{\beta_{1}}\left(X_{d}^{c}\right)^{\beta_{2}}} .
\end{aligned}
$$

The constants $H_{1}, H_{2}, H_{3}$, and $H_{4}$ are given by

$$
\begin{aligned}
& H_{1}=\left(q L\left(X_{n}\right)-q U_{i} X_{n}-\tau b / r\right)\left(X_{n}^{b}\right)^{-\gamma_{1}}+(1-q)\left(H_{2}+H_{3}\left(X_{n}^{b}\right)^{\gamma_{2}-\gamma_{1}}\right) \\
& H_{2}=\left(U_{0}-U_{i}\right) X_{i}^{b}-H_{3}\left(X_{i}^{b}\right)^{\gamma_{2}}+H_{4}\left(X_{i}^{b}\right)^{\beta_{2}} \\
& H_{3}=\frac{q L\left(X_{n}\right)-q U_{i} X_{n}-\gamma_{1}\left(q L\left(X_{n}\right)-q U_{i} X_{n}-\tau b / r\right)}{\left(\gamma_{1}-\gamma_{2}\right)(1-q) X_{n}^{\gamma_{2}}} \\
& H_{4}=\frac{\left(\gamma_{2}-\gamma_{1}\right) H_{3}\left(X_{i}^{b}\right)^{\gamma_{2}}-\left(1-\gamma_{1}\right)\left(U_{0}-U_{i}\right) X_{i}^{b}}{\left(\beta_{2}-\gamma_{1}\right)\left(X_{i}^{b}\right)^{\beta_{2}}}
\end{aligned}
$$




\section{References}

Alanis, E., Chava, S. and Kumar, P. (2018), 'Shareholder Bargaining Power, Debt Overhang, and Investment', The Review of Corporate Finance Studies 7(2), 276-318.

URL: https://doi.org/10.1093/rcfs/cfy005

Asquith, P., Gertner, R. and Scharfstein, D. (1994), 'Anatomy of financial distress: An examination of junkbond issuers', The Quarterly Journal of Economics 109(3), 625-658.

URL: https://EconPapers.repec.org/RePEc:oup:qjecon:v:109:y:1994:i:3:p:625-658.

Becker, B. and Ivashina, V. (2014), 'Cyclicality of credit supply: Firm level evidence', Journal of Monetary Economics 62, 76 - 93 .

URL: http://www.sciencedirect.com/science/article/pii/S0304393213001372

Blackwell, D. W. and Kidwell, D. S. (1988), 'An investigation of cost differences between public sales and private placements of debt', Journal of Financial Economics 22(2), 253 - 278.

URL: http://www.sciencedirect.com/science/article/pii/0304405X88900712

Broadie, M. and Chernov, Mikhailand Sundaresan, S. (2007), 'Optimal debt and equity values in the presence of chapter 7 and chapter 11', The Journal of Finance 62(3), 1341-1377.

URL: https://onlinelibrary.wiley.com/doi/abs/10.1111/j.1540-6261.2007.01238.x

Chen, H., Maslar, D. A. and Serfling, M. (2020), 'Asset redeployability and the choice between bank debt and public debt', Journal of Corporate Finance 64, 101678.

URL: http://www.sciencedirect.com/science/article/pii/S092911992030122X

Colla, P., Ippolito, F. and Li, K. (2013), 'Debt specialization', The Journal of Finance 68(5), 2117-2141.

URL: https://onlinelibrary.wiley.com/doi/abs/10.1111/jofi.12052

Colonnello, S., Efing, M. and Zucchi, F. (2019), 'Shareholder bargaining power and the emergence of empty creditors', Journal of Financial Economics 134(2), 297 - 317.

URL: http://www.sciencedirect.com/science/article/pii/S0304405X19300868

Crouzet, N. (2017), 'Aggregate Implications of Corporate Debt Choices', The Review of Economic Studies 85(3), 1635-1682.

URL: https://doi.org/10.1093/restud/rdx058

Danis, A. and Gamba, A. (2018), 'The real effects of credit default swaps', Journal of Financial Economics $\mathbf{1 2 7}(1), 51-76$.

URL: http://www.sciencedirect.com/science/article/pii/S0304405X17302556

Davydenko, S. A. and Strebulaev, I. A. (2007), 'Strategic actions and credit spreads: An empirical investigation', The Journal of Finance 62(6), 2633-2671.

URL: https://onlinelibrary.wiley.com/doi/abs/10.1111/j.1540-6261.2007.01288.x 
Denis, D. J. and Mihov, V. T. (2003), 'The choice among bank debt, non-bank private debt, and public debt: evidence from new corporate borrowings', Journal of Financial Economics 70(1), 3- 28.

URL: http://www.sciencedirect.com/science/article/pii/S0304405X03001405

Diamond, D. W. and He, Z. (2014), 'A theory of debt maturity: The long and short of debt overhang', The Journal of Finance 69(2), 719-762.

URL: https://onlinelibrary.wiley.com/doi/abs/10.1111/jofi.12118

Fan, H. and Sundaresan, S. M. (2000), 'Debt Valuation, Renegotiation, and Optimal Dividend Policy', The Review of Financial Studies 13(4), 1057-1099.

URL: https://doi.org/10.1093/rfs/13.4.1057

Favara, G., Schroth, E. and Valta, P. (2012), 'Strategic default and equity risk across countries', The Journal of Finance 67(6), 2051-2095.

URL: https://onlinelibrary.wiley.com/doi/abs/10.1111/j.1540-6261.2012.01781.x

Gilson, S. C., John, K. and Lang, L. H. (1990), 'Troubled debt restructurings: An empirical study of private reorganization of firms in default', Journal of Financial Economics 27(2), 315 - 353.

URL: http://www.sciencedirect.com/science/article/pii/0304405X90900599

Hackbarth, D., Hennessy, C. A. and Leland, H. E. (2007), 'Can the Trade-off Theory Explain Debt Structure?', The Review of Financial Studies 20(5), 1389-1428.

URL: https://doi.org/10.1093/revfin/hhl047

Hackbarth, D. and Mauer, D. C. (2012), 'Optimal Priority Structure, Capital Structure, and Investment', The Review of Financial Studies 25(3), 747-796.

URL: https://doi.org/10.1093/rfs/hhr129

Hackbarth, D., Rivera, A. and Wong (2019), 'Optimal short-termism', Working paper pp. 1-49.

Hennessy, C. A. (2004), 'Tobin's q, debt overhang, and investment', The Journal of Finance 59(4), 17171742 .

URL: https://onlinelibrary.wiley.com/doi/abs/10.1111/j.1540-6261.2004.00677.x

Leland, H. E. (1994), 'Corporate debt value, bond covenants, and optimal capital structure', The Journal of Finance 49(4), 1213-1252.

URL: https://onlinelibrary.wiley.com/doi/abs/10.1111/j.1540-6261.1994.tb02452.x

Leland, H. E. (1998), 'Agency costs, risk management, and capital structure', The Journal of Finance 53(4), 1213-1243.

URL: https://onlinelibrary.wiley.com/doi/abs/10.1111/0022-1082.00051

McDonald, R. and Siegel, D. (1986), 'The Value of Waiting to Invest*', The Quarterly Journal of Economics 101(4), 707-727.

URL: https://doi.org/10.2307/1884175 
Morellec, E., Valta, P. and Zhdanov, A. (2015), 'Financing investment: The choice between bonds and bank loans', Management Science 61(11), 2580-2602.

URL: https://doi.org/10.1287/mnsc.2014.2005

Myers, S. C. (1977), 'Determinants of corporate borrowing', Journal of Financial Economics 5(2), 147 - 175. URL: http://www.sciencedirect.com/science/article/pii/0304405X77900150

Rauh, J. D. and Sufi, A. (2010), 'Capital Structure and Debt Structure', The Review of Financial Studies 23(12), 4242-4280.

URL: https://doi.org/10.1093/rfs/hhq095

Shibata, T. and Nishihara, M. (2015a), 'Investment-based financing constraints and debt renegotiation', Journal of Banking Finance 51, 79 - 92.

URL: http://www.sciencedirect.com/science/article/pii/S0378426614003525

Shibata, T. and Nishihara, M. (2015b), 'Investment timing, debt structure, and financing constraints', European Journal of Operational Research 241(2), 513 - 526.

URL: http://www.sciencedirect.com/science/article/pii/S0377221714007322

Sundaresan, S. and Wang, N. (2007), 'Investment under uncertainty with strategic debt service', American Economic Review 97(2), 256-261.

URL: https://www.aeaweb.org/articles?id=10.1257/aer.97.2.256

Sundaresan, S., Wang, N. and Yang, J. (2015), 'Dynamic Investment, Capital Structure, and Debt Overhang*', The Review of Corporate Finance Studies 4(1), 1-42.

URL: https://doi.org/10.1093/rcfs/cfu013

Wong, T.-Y. and Yu, J. (2020), 'Credit default swaps and debt overhang', SSRN Working paper pp. 1-48. 